\title{
Herpetological assemblages of the Pilbara biogeographic region, Western Australia: ecological associations, biogeographic patterns and conservation
}

\author{
Paul Doughty ${ }^{1}$, James K. Rolfe ${ }^{2}$, Allan H. Burbidge ${ }^{2}$, David J. Pearson ${ }^{2}$ \\ and Peter G. Kendrick ${ }^{3}$
}

\author{
${ }^{1}$ Department of Terrestrial Vertebrates, Western Australian Museum, 49 Kew Street, Welshpool, \\ Western Australia 6106, Australia. Email: paul.doughty@museum.wa.gov.au \\ ${ }^{2}$ Department of Environment and Conservation, PO Box 51, Wanneroo, Western Australia 6946, Australia. \\ ${ }^{3}$ Department of Environment and Conservation, PO Box 835, Karratha, Western Australia 6714, Australia.
}

\begin{abstract}
The Pilbara region has one of the most diverse reptile assemblages in the world and includes many typical arid zone species as well as many saxicoline endemics. We present the results of a four-year survey of the region during which pitfall trap lines were used to sample 297 quadrats for a total of two weeks in spring and in autumn. The quadrats were located across the region and were chosen to sample the main substrate types. Environmental variables were measured to characterise the soil as well as the geomorphic, vegetative and climatic setting of each quadrat. We used the program PATN to expose patterns in species composition among quadrats, and in relation to the environmental variables.
\end{abstract}

A strong signal for community structure emerged that was linked to surface type. Broad rock, clay, sand and loam categorisations seemed to explain most assemblage composition, with climatic variables showing only weak influence. However, many taxa occurred across several surface types, reflecting the close juxtaposition of habitats within the region, wide dispersion of some taxa, and perhaps the influence of recent environmental history including anthropogenic changes.

Examination of biogeographic characteristics of the species groups indicated strong endemism for taxa that preferred rocky substrates. In addition, many saxicoline Pilbara taxa have ranges that extend south into rocky areas of the Gascoyne, western Murchison and adjacent areas. Sandy habitats similar to those found in the Pilbara are widespread across Australia's arid zone, and accordingly few endemic taxa showed a preference for sandy surface types, and taxa with such preferences have distributions extending far beyond the Pilbara. The sandy areas of the coastal plain in the Roebourne subregion contained many taxa from Dampierland and the Great Sandy Desert to the north and north-east, as well as some taxa from the rich sand-adapted fauna of the Carnarvon region to the south. Some endemic taxa are associated with clay in the region, although clay surfaces were not as extensive as the rocky, loamy and sandy surfaces. Species associated with the fine-textured soils of the mulga woodlands in the southern part of the region appear to be an extension of herpetofaunal communities of regions to the south.

Herpetofauna composition at the regional scale appears to have persisted, and patterns discerned in our analysis appear robust, despite the changes that have accompanied European colonisation in the Pilbara, including pastoralism, changed fire regimes, weeds, introduced animals, mining and infrastructure. However, the existing reserve system does not adequately capture the region's herpetofaunal diversity, especially the endemic taxa in the Fortescue and Roebourne subregions, and there are likely to have been changes in community composition at the local level.

Keywords - lizard, frog, PATN, Pilbara Biodiversity Survey, snake, substrate, arid 


\section{INTRODUCTION}

Australia possesses some of the most diverse reptile assemblages in the world (Pianka 1986; Greer 1989), and the Pilbara region of Western Australia (WA) (Figure 1) is especially species-rich. Positioned in a north-western corner of Australia, the Pilbara is a large area of rocky terrain (the Pilbara craton) almost entirely surrounded by sandy arid regions (the Gascoyne and western Murchison regions immediately to the south also have extensive though dispersed rocky areas). In addition to the rocky hills and gorges that the Pilbara is known for, there is an abundance of other surface types (i.e. surface geologies) including screes, wide expanses of colluvial and alluvial sands, loams and cracking clays. The Pilbara region has a tropical arid climate with low annual rainfall, and lies below the Kimberley region from which cyclones travel south during summer, producing irregular large rainfall events. This characteristic, coupled with the rugged topography of the region, results in the Pilbara receiving slightly higher rainfall than other regions in the arid zone. Reflecting its geographic setting on the western edge of the continent, the Pilbara region has a diverse biota consisting of representatives of northern tropical as well as southern taxa; of arid and semi-arid faunal elements; and an abundance of endemic species associated with rocky surfaces that have evolved in isolation from the rest of the continent (How et al. 1991; Burbidge et al. 2006; How and Cowan 2006; McKenzie et al. 2009).

Analyses of reptile diversity at global and continental scales have shown very high densities of species in the central western deserts and the Pilbara region (Schall and Pianka 1978; James and Shine 2000; How and Cowan 2006; Powney et al. 2010). However, an analysis based only on vouchered specimens (rather than extrapolations of the poorlysampled central western deserts using Cogger's $[1975,2000]$ range maps) clearly identified the Pilbara region as the area with the greatest reptile diversity in WA (How and Cowan 2006, figure 8). Among lizard groups, the Pilbara has the most gecko species in Australia, goannas are also reasonably diverse, and dragons and skinks have high levels of diversity (Powney et al. 2010, figure 3).

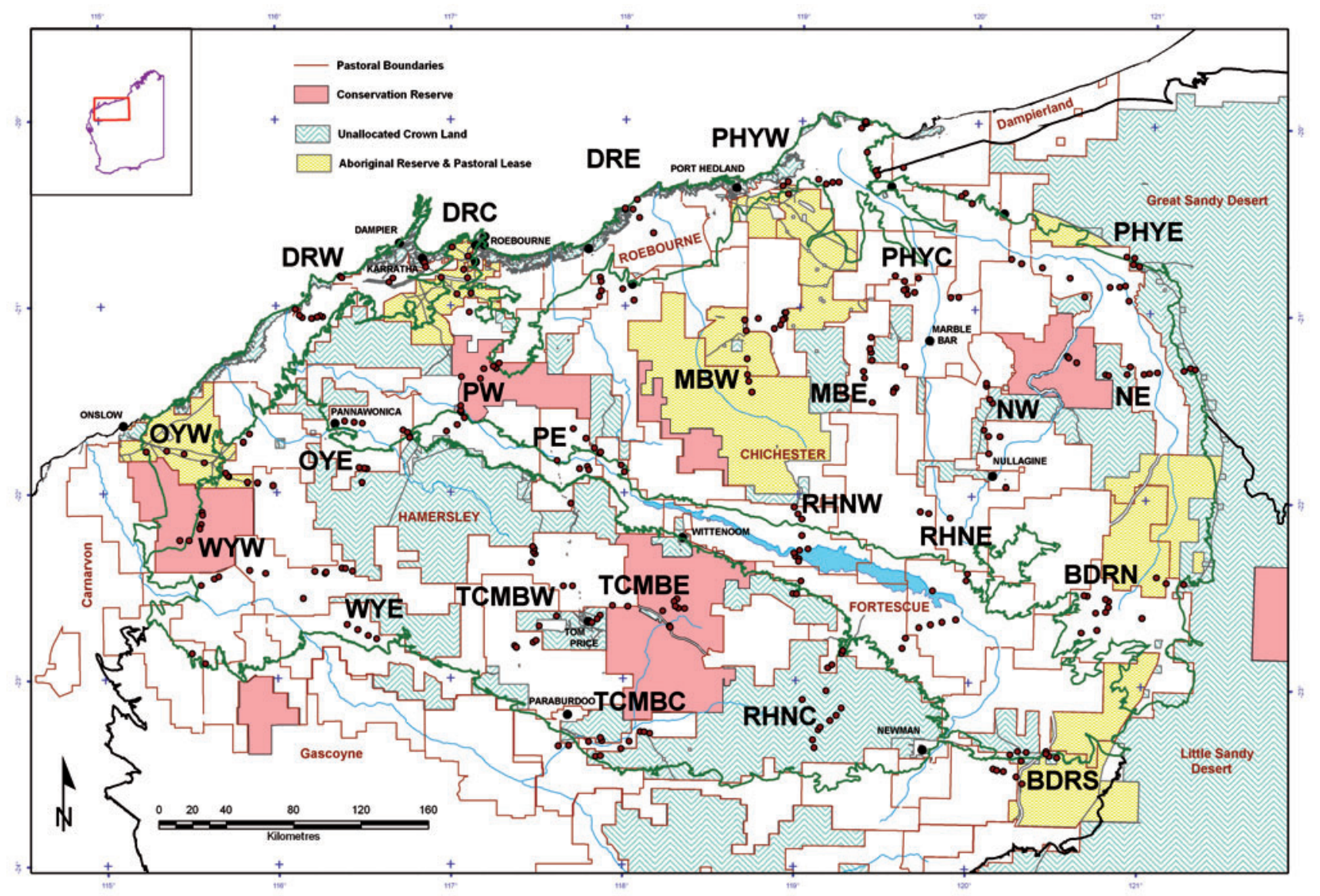

Figure 1 Map of the Pilbara Biogeographic Region (Thackway and Cresswell 1995; Department of Environment, Water, Heritage and the Arts 2009) showing quadrat locations, towns, main rivers (blue lines), land tenure, sub-regions (green lines), and surrounding regions (black lines). 
Unlike that of other arid zone regions of similar size in Australia, the Pilbara herpetofauna has a large number of endemic species. All major herpetofaunal groups that occur within the region have some endemic species, with frogs, goannas and blind snakes having two endemic species each, dragons and terrestrial snakes three endemic species each, and the highest number of endemics in geckos (including pygopods) with 10 species and skinks with 17 species. For these latter two groups, these figures translate to $\sim 25 \%$ endemic species confined to the Pilbara craton and $\sim 33 \%$ endemic to the combined Pilbara-western Murchison region that contains rocky areas. These figures represent much higher levels of endemism in the region compared to other similar-sized areas of the Australian arid zone (e.g. How and Cowan 2006). The majority of these endemic species are saxicoline and do not extend into the sandy deserts that surround the Pilbara, although there are connections to the rocky western Murchison and neighbouring regions to the south. There is only one species of freshwater turtle, with a range extending widely to the south and inland of the Pilbara. Saltwater crocodiles are occasionally sighted on the coast along with other marine reptiles such as sea turtles and sea and mangrove snakes.

Reptiles and frogs can provide informative species-habitat associations and biogeographic patterns for several reasons. Unlike many invertebrates, they are large and abundant enough to observe in sufficient numbers so that their habitat preferences can be interpreted. Their taxonomy is relatively well understood and they are far more diverse than small terrestrial mammals and microbats, resulting in diverse assemblages containing taxa with an array of distribution patterns that can be used to test and reveal patterns of habitat preference and biogeography. Unlike birds and most mammals, frogs and reptiles have limited capabilities of dispersal. Speciation and the evolution of narrow habitat preferences are thus more likely due to this lack of mobility (exceptions are largebodied reptiles such as snakes and goannas). This factor is likely to be of major importance in interpreting distribution patterns within the Pilbara.

The structure of reptile communities has been studied at a number of sites in arid Australia (e.g. Pianka 1986, 1996; James 1994; McKenzie et al. 2000b; Cowan and How 2004; Rabosky et al. 2007). Few of these studies, however, have examined geographic patterns in assemblage composition and, of those that have, the study areas have been in predominantly sandy regions. As a step towards understanding the biogeographic relationships of the Pilbara herpetofauna, and to provide a better basis for conservation management, our major objectives were to describe the assemblages of herpetofauna across the region, analyse the relationships between species occurrences and attributes of the study area's physical environment, and identify predictors of species composition across the study area.

Since the Pilbara is a rocky arid region with a diverse mixture of biotic elements, a secondary goal was to explore the biogeographic relationships of the species forming the Pilbara herpetofauna. In particular, we were interested in where Pilbara taxa and their closest relatives were distributed outside the region as well as within the Pilbara. Because the region has large numbers of species that are endemic compared to other arid zone regions, we further explored the historical and environmental characteristics that may have induced some groups to speciate more than others within the Pilbara.

Much of the Pilbara is used for extensive cattle grazing (and formerly also sheep), in some places for as long as 100 years (McKenzie et al. 2009). This has resulted in widespread environmental degradation, especially in riparian areas and areas of more productive soils. While mining has been an important land use for a similar length of time, the development of the iron ore industry since the 1960s and, more recently, natural gas has resulted in more intensive mining and exploration activity. This has increased the rate of habitat change due to anthropogenic disturbances, including changed fire regimes, feral animal densities, weed encroachment and hydrological changes. An understanding of geographic patterns in Pilbara herpetofauna can provide an objective basis on which to help guide the acquisition of suitable lands for nature conservation, clarify the conservation status of key species and facilitate future land management.

\section{METHODS}

\section{Study area}

The study area comprised the Pilbara IBRA biogeographic region (Thackway and Cresswell 1995), extending from the coast near Port Hedland (latitude $20^{\circ} \mathrm{S}$ ) south to near Newman (latitude $23^{\circ} 30^{\prime} \mathrm{S}$ ), and from near Onslow (longitude $115^{\circ} \mathrm{E}$ ) east to approximately longitude $121^{\circ} \mathrm{E}$ (Figure 1). The Pilbara craton is one of Australia's major geological blocks (Trendall 1990), with landscapes structured by hard rocks laid down in Archaean times, 2.5 to 3.5 billion years ago, making them some of the oldest exposed rocks on Earth. Most of the landscape is either rocky or colluvial in nature, although the coastal plains are predominantly alluvial deposits close to river outflows. Vegetation in the Pilbara consists predominantly of tree- and shrub-steppe communities with Eucalyptus trees, Acacia shrubs and hummock grasses such as Triodia pungens and $T$. wiseana (Beard 1990). The region has an arid tropical climate (Beard 1990; Leighton 2004), influenced by 
two air masses over the region: the Indian Tropical Maritime air moving in from the west or northwest, and tropical continental air from the interior. Maximum temperatures often exceed $40^{\circ} \mathrm{C}$ in the hottest part of the year (November-March), while in winter the maximum temperature falls to about $25^{\circ} \mathrm{C}$. Rainfall is low and variable, with average annual rainfall ranging from about $200-350 \mathrm{~mm}$ across the region, and average yearly evaporation greatly exceeding average yearly rainfall. The area is subject to occasional tropical cyclones, usually between January and April. More detailed overviews of the study area are provided elsewhere (van Vreeswyk et al. 2004; McKenzie et al. 2009).

\section{Sampling methodology}

As part of a wider survey of biogeographic patterns in the biota of the Pilbara (McKenzie et al. 2009), the $179,000 \mathrm{~km}^{2}$ study area was divided into 24 survey areas (Figure 1). These were positioned to allow sampling across the extent of the Pilbara bioregion, and across major environmental gradients to ensure wide coverage of habitat types throughout the region. Quadrats were placed in typical examples of the major surface geological units in each study area. Within each survey area, 12 or 13 quadrats were positioned to sample the area's geomorphic profiles. This provided a total of over 300 quadrats. Some quadrats, however, were burnt between the first and second sampling sessions, or were inaccessible due to flooding at other times, so the final number of quadrats included in the analysis was 297. Recently burnt quadrats were avoided during quadrat selection because fire alters reptile community composition in these landscapes (How and Dell 2004), as we were aiming to detect broad-scale biogeographic patterns rather than short-term impacts of fire. Further details concerning quadrat selection are provided in McKenzie et al. (2009), along with the quadrat locations.

A $50 \times 50 \mathrm{~m}$ vegetation plot was established on each study quadrat (S. van Leeuwen, unpublished data), and marked with metal posts at each corner. Two pitfall trap lines were then installed, with one on each side of the vegetation plot. Each line was made up of five pits connected by a $30 \mathrm{~m}$ drift fence of black aluminium flywire ( $30 \mathrm{~cm}$ high) that began near the corner posts that defined the vegetation quadrat. A $4-5 \mathrm{~cm}$ 'foot' was folded into the base of the flywire fence, with the fence then being held in place on the substrate with soil or small rocks. Usually the line was installed nearly parallel to but angled slightly away from the perimeter of the plot. Occasionally the proposed trap line alignment would enter a different habitat type, and in these instances the line was shifted to remain in the same habitat type as the vegetation plot to avoid ecotones. The pits used were $125 \mathrm{~mm}$ diameter PVC bore casing, each $60 \mathrm{~cm}$ deep, and positioned at $7.5 \mathrm{~m}$ intervals along the fence, including one at the beginning and one at the end. In rocky areas, it was often necessary to drill and blast the rocky substrate to enable insertion of the pit traps. A 2-litre plastic jar was placed in the base of each pit, with a cone-shaped plastic funnel positioned in the mouth of the jar to reduce escapes, particularly climbing species such as the gecko genus Gehyra that can climb smooth vertical surfaces owing to their welldeveloped adhesive toe pads (Burbidge et al. 2004; JKR, pers. obs.). Each pit had a unique alphanumeric code written on the inside wall near the top that observers recorded for each capture in order to verify the quadrat location. Once the pits were in place, they were capped using tight-fitting $140 \mathrm{~mm}$ rubberised plastic caps. The caps had small holes to prevent pit-traps from floating out of the ground during flood events. These caps were removed to activate the pit during sampling periods. Although the use of other trap types, such as Elliott traps and funnel traps, could have increased the trapping efficiency for some species, these types were not deployed because they are unsuitable for use in broad-scale surveys in areas where temperatures can be very high (Thompson and Thompson 2009).

Reptiles and frogs were pit-trapped at each quadrat for a minimum of seven nights in each sampling season. The survey areas were sampled in such a way that quadrats were sampled in different years to minimise both seasonal climatic influence across years and loss due to fires (McKenzie et al. 2009). Because the quadrats were sampled in clumps (for logistic reasons) it is not possible to test for temporal effects in the data, due to potential confusion with spatial effects. There may therefore be some undetected temporal effects in our data, but we believe that our design would have minimised any such effects. The first 12 survey areas were sampled in October 2004 and re-sampled in May 2005. The second set of 12 survey areas was sampled during October 2005, then re-sampled in May 2006. A few quadrats in BDRN, PHYC and PHYE were not sampled in the second sampling session because access was not possible due to heavy rainfall. The relevant BDRN quadrats were re-sampled in December 2005 and the PHYC and PHYE quadrats in October 2006. For the second sampling of survey area TCMBE, pits were open for only six nights. As different sampling methods and trap types have different outcomes in terms of species presence and estimates of relative abundance (e.g. Rolfe and McKenzie 2000), we also included occurrence data from accidental captures in a systematic invertebrate 
sampling program using five wet pits, sampling over an entire year within the bounds of the vegetation plot at every quadrat that we sampled (Durrant et al. 2010; Guthrie et al. 2010). This meant that we were more likely to have sampled the full assemblage of species present at a given quadrat. Systematic active searches were not undertaken to complement the pitfall trapping owing to the large number of pitfall traps open simultaneously. A previous analysis of survey data indicated that such searches may have contributed little to the results (Rolfe and McKenzie 2000). Voucher specimens were lodged in the Western Australian Museum (WAM).

Overall sampling efficiency for reptile species was assessed using both the modified Chao2 (Chao 1987) and the modified incidence-based coverage (ICE) (Lee and Chao 1994) estimators in the EstimateS software (Colwell 2006).

\section{Analysis}

The analytical approach taken was an exploratory design based on the assumption that spatial distribution reflects an underlying correlation with environmental factors (Austin 1991). More than 40 climatic, geomorphic, soil and vegetation attributes were determined for each quadrat (McKenzie et al. 2009). Using ANUCLIM (McMahon et al. 1995), 17 climatic attributes were derived for each quadrat. These consisted of annual, seasonal average and range values for temperature and precipitation. Soil chemical and texture values for each quadrat were derived from sub-samples collected at a depth of $2-5 \mathrm{~cm}$ from 10 points, then bulked. These included nitrogen, phosphorus, potassium, $\mathrm{pH}$, electrical conductivity, organic carbon, clay-siltsand percentages and magnesium (cf. Burbidge et al. 2004).

We used both unconstrained ordination (SSH) and cluster analysis from the program PATN (Belbin 1995) to reveal patterns of quadrat similarity and species composition in the data matrix. Briefly, the Czekanowski (Bray-Curtis) association measure was used to compare the quadrats according to similarities in their species composition, and the association measure 'two-step' (Belbin 1980) was used to determine the quantitative relationship between each pair of species as a basis for clustering species that normally co-occurred at the same quadrats. For both measures of association, a modified version of 'unweighted pair group arithmetic averaging' hierarchical clustering strategy was used (flexible UPGMA - Sneath and Sokal 1973; Belbin 1995), with the clustering parameter (Beta) set to -0.1 . This procedure is appropriate for ecological presence-absence data and is robust to variations in species abundance patterns and hence sampling efficiencies (Faith et al. 1987; Belbin 1991). The partition structure of the resulting quadrat-dendrogram was used as a summary of compositional patterns across the study area. Quadrat physical attributes that conformed most closely to the overall partition structure were assessed for statistical significance using Kruskal-Wallis one-way analysis of variance by ranks (the GSTA module in PATN [Belbin 1995]). Partitioning of the overall dendrogram was judged visually (cf. Figure 3), supplemented by the authors' previous experience with the species together with examination of putative groups and the two-way table, based on extrinsic properties of the component quadrats or species.

While the approach outlined above is useful for examining the overall structure of the dendrogram, it obscures the relationships exhibited by most of the groups at the point where a group separates from the remainder of the dataset. We therefore used the simple stepwise approach of examining each fusion event separately. This provides a more detailed and more realistic interpretation of the relationships exhibited by the different components of the fauna. The level of significance between pairs of groups for individual physical attributes was tested using Mann-Whitney U-tests. At each fusion point in the dendrogram's partition structure starting from the top (two groups), we compared the two newly formed groups, provided each group had at least five members. For example, at the second fusion point there are three groups, but only one of the initial groups is divided so the resultant two 'new' groups were compared using Mann-Whitney U-tests.

Species assemblages identified from the species classification were interpreted in terms of the known habitat preferences of their component species throughout their ranges elsewhere in Australia (e.g. How et al. 1988; Storr et al. 1999, 2002; McKenzie et al. 2000b; Burbidge et al. 2004; Tyler and Doughty 2009) and our previous field experience in other parts of Western Australia. The use of such extrinsic information on habitat preferences and distribution provides an indication of whether the classification is biologically meaningful.

In any spatial data such as those collected here, it is possible that there may be some degree of spatial autocorrelation, i.e. locations close to each other may exhibit more similar values (e.g. lists of species present) than those further apart (Dorrman et al. 2007). To test for this, we used PATN to generate an association matrix based on Euclidean distance between quadrats, and converted this to a vector. Similarly, we took the Bray-Curtis matrix (based on reptile occurrences at the same quadrats) and converted this to a vector. Plotting one vector against the other provides a scatter plot (Figure 


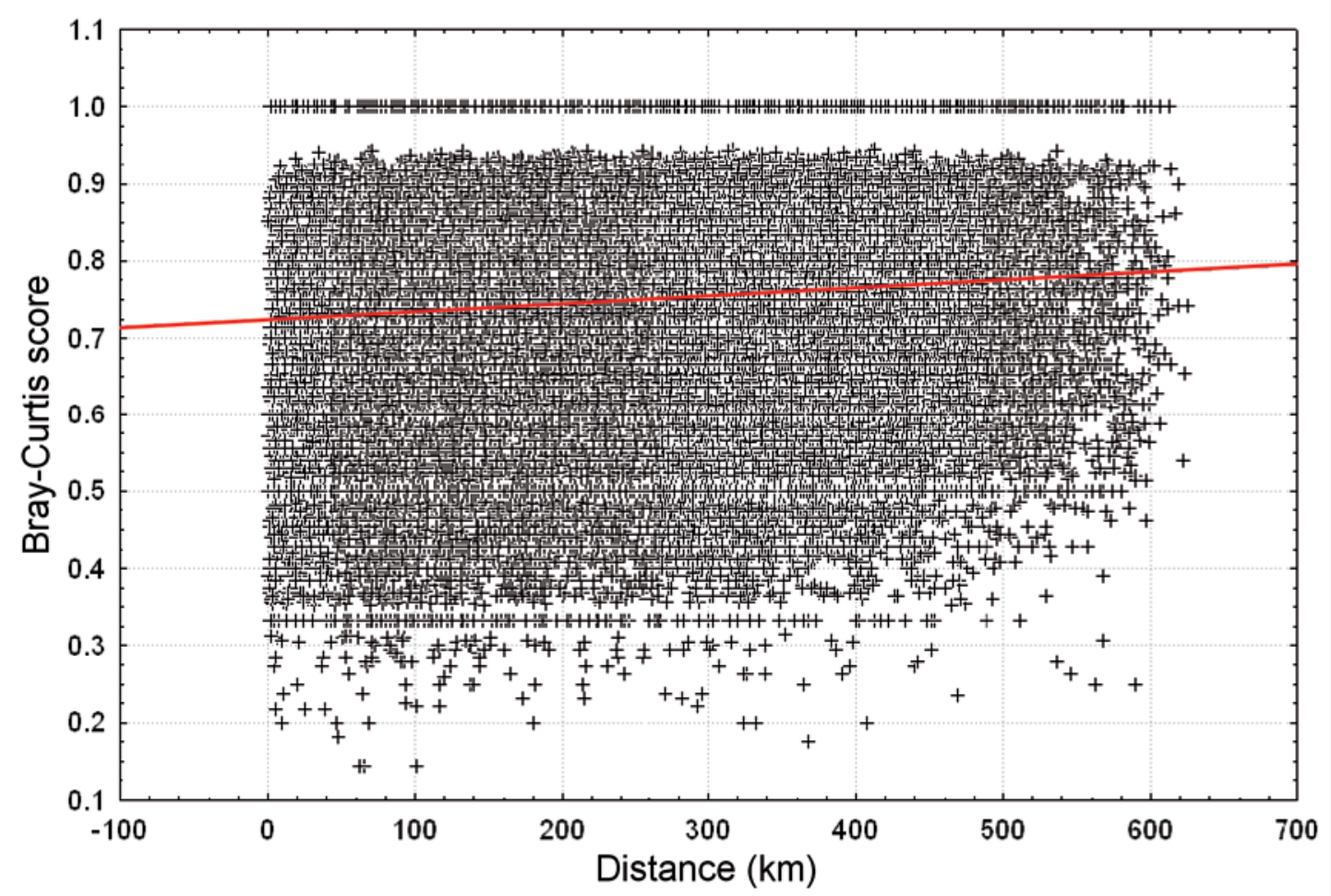

Figure 2 The relationship between Bray-Curtis scores of reptile species occurrences and Euclidean distances between sampling quadrats, for 297 quadrats in the Pilbara region. A line of best fit with a slope of zero would indicate no correlation. The observed line of best fit $(Y=0.725+0.000099 X)$, and the occurrence of a few quadrats with low Bray-Curtis scores at short distances, reveal a small degree of correlation suggesting a very weak effect between nearby quadrats.

2) in which the slope of the line of best fit is a measure of spatial correlation, with a slope of zero indicating a complete absence of correlation. In this case, the line was represented by the equation $\mathrm{Y}=$ $0.725+0.000099 \mathrm{X}$, indicating a small but detectable degree of correlation. Examination of the scatter plot indicated that most of the effects of correlation would be expected at inter-quadrat distances of less than about $50 \mathrm{~km}$. Because the effects were small, we did not correct for them in subsequent analyses.

Species conservation status was determined within ArcMap ${ }^{\mathrm{TM}} 9.2$ (ESRI, Redlands, CA, U.S.A.) by overlaying conservation reserve boundaries on about 26,000 point records of species occurrence from the WAM database and records from the current survey.

\section{RESULTS}

\section{Sampling efficiency}

The large number of quadrats (297) and pit trap nights from the dry pits $(41,560)$ and wet pits $(>400,000)$ resulted in over 11,000 captures with a mean of $11.2 \pm 4.2 \mathrm{SD}$ species per quadrat (range
2-27). The sampling greatly clarified the spatial distributions and morphological range of variation of many species within the region. In addition, collection of voucher specimens has facilitated the taxonomic revision of some groups, and several new species of reptiles discovered during the survey are the subject of current taxonomic work (P. Doughty et al., unpublished data).

Table 1 lists all taxa caught during our survey as well as the pool of known taxa occurring within the Pilbara IBRA region based on records from the WAM. Taxa were included in subsequent analysis only if they were reliably captured by our sampling methods (cf. Rolfe and McKenzie 2000). This approach aimed to reduce problems of unreliable 'absence' data in the presence-absence matrix. Table 2 lists the groups excluded and the reasons for excluding them. Frogs and pygopods (legless geckos) were small enough to be captured but were not trapped reliably. Terrestrial snakes, large varanids and blue-tongue skinks were generally too large for our traps and so were excluded. An exception was the subterranean blind snakes, which are small and did not appear to actively avoid traps. Since 
Table 1 Terrestrial frog and reptile taxa known from the Pilbara IBRA region, based on the collections held by the Western Australian Museum. Numbers refer to the number of quadrats where the taxon was trapped during our survey. Key: $\uparrow=$ species excluded from analysis because they were not likely to be caught by our trapping methods or were captured too infrequently ( $\leq 1$ quadrat; see text and Table 2$){ }^{*}$ = naturalised exotic species.

\section{Frogs}

Hylidae

Cyclorana australis

Cyclorana maini

Cyclorana platycephala

Litoria rubella

Limnodynastidae

Neobatrachus aquilonius

Neobatrachus sutor

Notaden nichollsi

Platyplectrum spenceri

Myobatrachidae

Pseudophryne douglasi

Uperoleia glandulosa

Uperoleia micromeles

Uperoleia saxatilis

Uperoleia talpa

\section{Reptiles}

Cheluidae

Chelodina steindachneri

Diplodactylidae

Crenadactylus sp. nov.

Diplodactylus conspicillatus

Diplodactylus galaxias

Diplodactylus granariensis rex

Diplodactylus mitchelli

Diplodactylus pulcher

Diplodactylus savagei

Lucasium stenodactylum

Lucasium wombeyi

Lucasium 'woodwardi'

Oedura marmorata

Rhynchoedura ornata

Strophurus ciliaris aberrans

Strophurus elderi

Strophurus jeanae

Strophurus strophurus

Strophurus wellingtonae

Strophurus wilsoni

Carphodactylidae

Nephrurus laevissimus

Nephrurus levis pilbarensis

Nephrurus wheeleri cinctus

Underwoodisaurus seorsus
Gekkonidae

Gehyra 'fenestra'

Gehyra pilbara

Gehyra punctata

Gehyra variegata/purpurascens

Hemidactylus frenatus*

Heteronotia binoei

Heteronotia spelea

Heteronotia sp. A

Heteronotia sp. B

Pygopodidae

Delma borea

Delma butleri

Delma desmosa

Delma elegans

Delma haroldi

Delma nasuta

Delma pax

Delma tincta

Lialis burtonis

Pygopus nigriceps nigriceps

Agamidae

Amphibolurus g. gilberti

Amphibolurus longirostris

Caimanops amphiboluroides

Ctenophorus c. caudicinctus

Ctenophorus caudicinctus mensarum

Ctenophorus femoralis

Ctenophorus isolepis isolepis

Ctenophorus isolepis gularis

Ctenophorus nuchalis

Ctenophorus reticulatus

Ctenophorus rubens

Ctenophorus scutulatus

Diporiphora pindan

Diporiphora valens

Diporiphora sp. nov.

Moloch horridus

Pogona minor minor

Pogona minor mitchelli

Tympanocryptis cephalus

Tympanocryptis sp. nov.

Scincidae

Carlia munda

Carlia triacantha

Cryptoblepharus buchananii

Cryptoblepharus plagiocephalus

Cryptoblepharus ustulatus

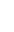

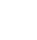

3

1

1

2

16

2

17

24

15

11

2

0

35

6

187

$+\quad 0$

$+\quad 1$

71

$+\quad 0$

38

30

$+\quad 0$

$+\quad 0$

7

13

$+\quad 1$

2

60

$+\quad 1$

3

15 
Ctenotus ariadnae

Ctenotus brooksi

Ctenotus calurus

Ctenotus duricola/piankai

Ctenotus grandis titan

Ctenotus hanloni

Ctenotus helenae

Ctenotus iapetus

Ctenotus leonhardii

Ctenotus maryani

Ctenotus mimetes

Ctenotus nasutus

Ctenotus nigrilineatus

Ctenotus pantherinus ocellifer

Ctenotus quattuordecimlineatus

Ctenotus robustus

Ctenotus rubicundus

Ctenotus rufescens

Ctenotus rutilans

Ctenotus saxatilis

Ctenotus schomburgkii (east)

Ctenotus schomburgkii (west)

Ctenotus serventyi

Ctenotus severus

Ctenotus uber uber

Cyclodomorphus m. melanops

Egernia aff. depressa

Egernia formosa

Egernia pilbarensis

Eremiascincus isolepis

Eremiascincus musious

Eremiascincus 'pallidus'

Eremiascincus richardsonii

Lerista bipes

Lerista aff. bipes

Lerista clara

Lerista flammicauda

Lerista ips

Lerista jacksoni

Lerista labialis

Lerista muelleri

Lerista neander

Lerista nevinae

Lerista petersoni

Lerista quadrivincula

Lerista rolfei

Lerista separanda

Lerista timida/amicorum

Lerista verhmens

Lerista zietzi

Liopholis striata

Menetia greyii

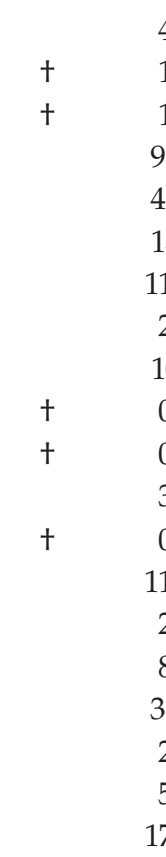

4

1

1

Menetia surda surda 64

Morethia ruficauda exquisita

Morethia ruficauda ruficauda

Notoscincus butleri

Notoscincus ornatus ornatus

Proablepharus reginae

Tiliqua multifasciata

Varanidae

Varanus acanthurus

Varanus brevicauda

Varanus caudolineatus/bushi

Varanus eremius

Varanus giganteus

Varanus gilleni

Varanus gouldii

Varanus panoptes rubidus

Varanus pilbarensis

Varanus tristis tristis

Typhlopidae

Ramphotyphlops ammodytes

Ramphotyphlops braminus*

Ramphotyphlops ganei

Ramphotyphlops grypus

Ramphotyphlops hamatus

Ramphotyphlops pilbarensis

Ramphotyphlops waitii

Boidae

Antaresia perthensis

Antaresia stimsoni stimsoni

Aspidites melanocephalus

Aspidites ramsayi

Liasis olivaceus barroni

Elapidae

Acanthophis pyrrhus

Acanthophis wellsi

Brachyurophis approximans

Demansia psammophis cupreiceps

Demansia rufescens

Furina ornata

Parasuta monachus

Pseudechis australis

Pseudonaja mengdeni

Pseudonaja modesta

Simoselaps anomalus

Simoselaps bertholdi

Suta fasciata

Suta punctata

Vermicella snelli 
they exhibited moderate trapping rates, they were included in the analysis. This left 101 taxa in the analysis.

Species accumulation curve analyses showed that our sampling methods were more than adequate for the survey at the regional level, which is the scale at which our investigation was focused. Taking the entire data set for the 297 quadrats (i.e. including singletons and other species excluded from the analysis), the ICE procedure produced an estimate of 159 species, and the Chao 2 procedure 156 species, from the 297 quadrats across the Pilbara region, compared with a field result of 147 species. Both estimates came to convergence after about 240 quadrats, after which no further species were added. Using the data set employed in our pattern analysis, but including singletons, the ICE procedure produced an estimate of 111 species and Chao2 110 species, compared with 109 observed, with both converging after about 170 quadrats. These results indicate that our methods were sufficient to document the herpetofauna of the region, once we had removed those groups that we considered not readily trappable by our methods (Table 2).

When species richness was estimated for each of the eight quadrat partition groups, the field sampling results ranged between $64 \%$ and $98 \%$ of the estimated values, with the higher values occurring in those groups with more quadrats (Table 3). This suggests that, while results for partition groups $\mathrm{F}-\mathrm{H}$ are likely to be quite robust, some caution is appropriate when interpreting results for the partition groups with smaller numbers of quadrats.
Inspection of actual accumulation curves for each of the 24 survey areas showed that the majority of curves flattened out after 6-10 days of trapping, with the wet pits (which were open for a whole year) adding an extra 3-26\% species per survey area, to give totals of 32-57 species per survey area. Accumulation curves for individual quadrats were much more variable but tended also to flatten out by the end of the sampling period. For most quadrats, by-catch from the wet pits added extra species to the total for the quadrat, so we were confident that our sampling was adequate.

As a further measure of sampling adequacy, we compared the taxa captured during the survey with historical data. The WAM database records the presence of 13 frog and 165 reptile taxa in the Pilbara IBRA region, of which we caught 11 (85\%) and $135(82 \%)$, respectively (Table 1$)$. Of the reptile taxa known from the Pilbara, 129 were considered 'trappable' using our methods, and of these 109 (85\%) were captured.

Some species were difficult to reliably differentiate morphologically from closely-related species or were described too late to be included in our analyses, and were combined in the analysis. The species pairs involved are similar ecologically, so combining taxa was viewed as conservative. The species pairs were the arboreal goannas Varanus caudolineatus and $V$. bushi (referred to as $V$. caudolineatus), the arboreal geckos Gehyra variegata and G. purpurescens (referred to as G. variegata), and the skinks Lerista timida and L. amicorum (referred to as L. timida) and Egernia cygnitos and E. epsisolus (referred to as E. aff. depressa); in each case, most specimens will be

Table 2 Rationale for exclusion of certain taxa from quantitative analyses of Pilbara herpetofauna.

\begin{tabular}{|c|c|}
\hline Taxa removed & Reason \\
\hline All frogs & $\begin{array}{l}\text { Captures were dependent on rainfall that is spatially and temporally } \\
\text { variable, and therefore were not consistent during the survey. }\end{array}$ \\
\hline Chelodina & Primarily aquatic; apart from juveniles, too large to fall into pit traps. \\
\hline All legless lizards (Pygopodidae) & $\begin{array}{l}\text { Many were too large to fall into pit traps and actively avoid them (pers. } \\
\text { obs.); legless lizards may be visually-oriented rather than chemically- } \\
\text { oriented predators, and therefore may not willingly forage in pits (v. } \\
\text { snakes). }\end{array}$ \\
\hline $\begin{array}{l}\text { Centralian Blue-tongue } \\
\text { (Tiliqua multifasciata) }\end{array}$ & Too large to fall into pit traps or actively avoided pits. \\
\hline All snakes except blind snakes & $\begin{array}{l}\text { Most snakes were too large to be captured in the pit traps, but blind } \\
\text { snakes are small enough to fall into pits without escaping. We caught } 222 \\
\text { blind snakes v. } 32 \text { individuals of all other snake taxa. }\end{array}$ \\
\hline $\begin{array}{l}\text { Large Varanus species (giganteus, } \\
\text { gouldii, panoptes rubidus and } t \text {. tristis) }\end{array}$ & $\begin{array}{l}\text { Too large to be captured by the pit traps (only } 9 \text { records: } 6 \text { small } \\
\text { individuals captured and } 3 \text { observations). }\end{array}$ \\
\hline
\end{tabular}


Table 3 The number of species observed in each of the eight quadrat groups identified on the basis of reptile occurrences at 297 Pilbara quadrats, and the species-richness estimated using the modified ICE and Chao2 estimators in EstimateS (Colwell 2006).

\begin{tabular}{ccccc}
\hline Quadrat Group & No. of quadrats & $\begin{array}{c}\text { No. of species } \\
\text { observed }\end{array}$ & ICE & Chao2 \\
\hline A & 12 & 23 & 35 & 29 \\
B & 11 & 21 & 33 & 31 \\
C & 30 & 56 & 84 & 85 \\
D & 18 & 42 & 63 & 52 \\
E & 23 & 55 & 74 & 78 \\
F & 44 & 73 & 88 & 82 \\
G & 67 & 54 & 56 & 55 \\
H & 92 & 67 & 72 & 70 \\
\hline
\end{tabular}

of the first-cited species. We also combined two recognised taxa with different habitat preferences: Ctenotus duricola and C. piankai (referred to as C. duricola), as current understanding of morphological and genetic variation precludes their separation at this time (D.L. Rabosky, pers. comm.). In other cases, new taxa were identified during the survey and are the subject of current taxonomic revisions by PD and colleagues. In some cases, available names for taxa that will be resurrected in taxonomic revisions in preparation are put in quotes, e.g. Lucasium 'woodwardi' for Pilbara and Murchison-Gascoyne populations of L. stenodactylum (Pepper et al. 2006); Gehyra 'fenestra' for large-bodied G. punctata (PD and M. Adams, unpublished data); and Eremiascincus 'pallidus' for western populations of E. fasciolatus (S. Mecke, PD and S. Donnellan, unpublished data). For two species, there were apparent differences in morphology between different parts of the Pilbara, and the different populations are indicated: Heteronotia aff. spelea (sp. A and sp. B) and Ctenotus schomburgkii (eastern and western colour forms; Storr et al. 1999).

\section{Reptile species classification}

Our analysis showed strong patterns of associations between reptile taxa and habitats (Figure 3). Some taxa showed very narrow habitat preferences, not occurring on other substrate types; however, other taxa occurred across a range of substrate types, often providing a mix of specialists and generalists within a species group in the species classification.

Statistics relating the occurrence of each taxon to environmental variables are shown in electronic Appendix 1, and a classification-ordered, twoway table is shown in electronic Appendix 2.
Examination of the PATN output revealed six major species groups based on bio-climatic and soil-geological characters. At this six-group level there was sufficient representation of taxa to identify a species group confidently, but with enough differentiation from other groups to allow meaningful comparisons. Figure 3 shows the six major species groups we discuss below, and Appendix 2 shows the table in detail including the taxon and quadrat labels; the members of each species group are also presented in Table 4 . We refer to fusion points in the dendrogram as 'divisions', for clarity, as we discuss the species classification dendrogram from few to many species groups.

The first division (Figure 3) separated species group 6 from the remaining taxa in the analysis. This group comprised taxa favouring sandy surfaces and species that generally just extended into the northern Pilbara from the sandplains and dunefields of Dampierland and the Great Sandy Desert, and included Diporiphora pindan, Lerista separanda (both new range extensions), Lucasium stenodactylum and Eremiascincus musious (Appendix 2). Table 5 presents measured variables that were significantly different between the two branches at the $P<0.0001$ and $P<$ 0.005 levels. Prominent variables that separated these two groups were the level of soil nutrients (total potassium, nitrogen, exchangeable calcium), silt and temperature (in the driest quarter and over the year). The soil variables are indicative of deep aeolian sands of neighbouring deserts. Also significant were latitude and longitude, to which the northeastern distribution of many of the species sampled in species group 6 was sensitive, with taxa having distributions that extend south from the Kimberley along the Dampierland IBRA region that separates the coast from the Great Sandy Desert. 
After the removal of the deep sand specialists (most from outside the Pilbara craton), the next division separated the remaining Pilbara taxa into two large assemblages, one with mainly saxicoline habits (species groups 4 and 5) and another containing species that preferred sandy and clayey surfaces, including loams (species groups 1-3). Environmental variables (see McKenzie et al. 2009) that differed between these assemblages with high significance were topographic ruggedness, amount of exposed bedrock, rock size and abundance, slope and other variables associated with rugged rocky habitats (Table 5). Examination of Figure 3 shows these two groups clearly, with the saxicoline species dominating many of the rugged quadrats (see below). Species groups 1-3, however, showed more generalist habits, with taxa occurring on most soil types including the lower slopes of rocky areas, but with an avoidance of rocky ridges (quadrat group $\mathrm{H}$; Figure 3).

Within the saxicoline assemblage (species groups 4 and 5), there were two dominant species that were captured most frequently on our quadrats - Ctenophorus c. caudicinctus (187 quadrats) and Ctenotus saxatilis (174 quadrats) (Table 1). These two taxa also occurred on less rocky surface types (Figure 3; Appendix 2), indicating tolerance for these surfaces, wide dispersal, high population densities within the region, close proximity of different habitat types near the quadrat or a combination of these and other factors. Other species in this assemblage were the specialised taxa associated with rock-surfaces such as the geckos Nephrurus wheeleri cinctus, Lucasium wombeyi, Gehyra punctata, G. 'fenestra', Diplodactylus galaxias and D. savagei, the skinks Ctenotus rubicundus and Egernia aff. depressa, and Varanus acanthurus. All these taxa have reddish colouration and many are restricted to the Pilbara region.

Within the saxicoline assemblage, species group 4 contained the majority of taxa favouring rugged terrain, including many obligate rock-surface dwellers (see above). However, some species in this group also occurred on other surfaces, especially clays and leaf litter associated with outcrops (e.g. skinks from the Lerista muelleri complex [muelleri, jacksoni, verhmens], Morethia ruficauda exquisita, Carlia munda, Menetia s. surda and the gecko Heteronotia binoei). This was the second-largest of the six species groups.

Within this assemblage, species groups 4 and 5 were separated by such variables as slope of the quadrat and topographic ruggedness, organic carbon, exchangeable magnesium and calcium and the annual range of temperatures (Table 5). Species group 5 comprised poorly-sampled and/ or geographically-restricted taxa also favouring rugged terrain but more eroded sites such as screes, cliffs and gorges (e.g. Heteronotia spelea, Egernia pilbarensis, Varanus pilbarensis). However, most species were represented by occurrence at only $2-6$ of the 297 quadrats across the study area (the exception was Lerista flammicauda at 15 quadrats), making interpretation difficult.

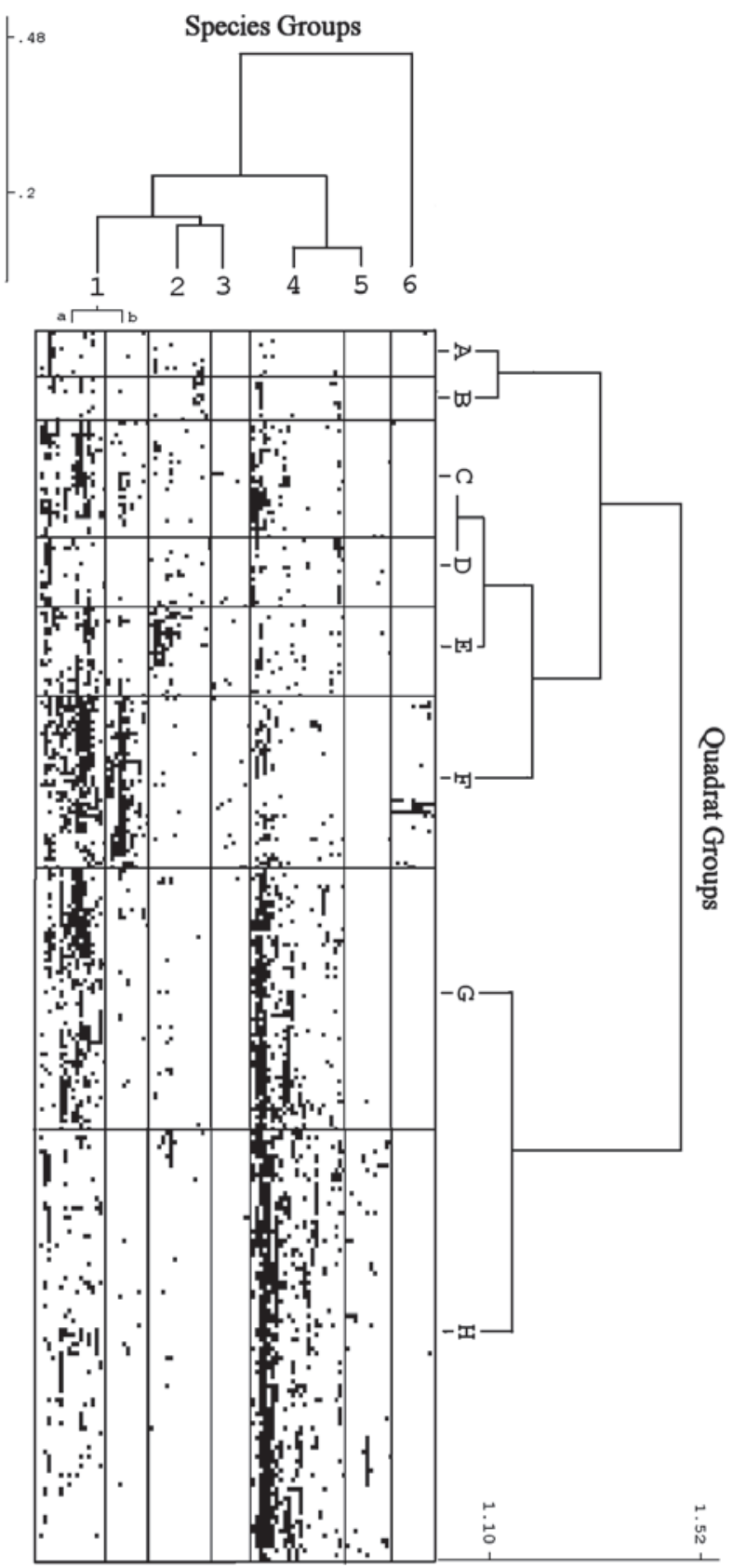

Figure 3 Six group species classification and eight group quadrat classification superimposed on a data matrix re-ordered according to these classification analyses of 101 reptile species sampled at 297 quadrats in the Pilbara biogeographic region (see text). 
Table 4 Composition of each of the species groups identified in the classification of Pilbara reptiles.

\begin{tabular}{|c|c|}
\hline Group & Component taxa \\
\hline 1 & $\begin{array}{l}\text { Amphibolurus longirostris, Ctenophorus i. isolepis, Ctenophorus nuchalis, Ctenotus duricola, Ctenotus grandis } \\
\text { titan, Ctenotus hanloni, Ctenotus helenae, Ctenotus pantherinus ocellifer, Ctenotus serventyi, Diplodactylus } \\
\text { conspicillatus, Diporiphora valens, Eremiascincus isolepis, Eremiascincus 'pallidus', Gehyra variegata, Lerista } \\
\text { bipes, Lerista clara, Lucasium 'woodwardi', Menetia greyii, Morethia ruficauda ruficauda, Nephrurus levis } \\
\text { pilbarensis, Notoscincus o. ornatus, Pogona m. minor, Ramphotyphlops ammodytes, Ramphotyphlops pilbarensis, } \\
\text { Rhynchoedura ornata, Strophurus elderi, Varanus brevicauda, Varanus eremius }\end{array}$ \\
\hline 2 & $\begin{array}{l}\text { Caimanops amphiboluroides, Cryptoblepharus plagiocephalus, Ctenophorus reticulatus, Ctenotus leonhardii, } \\
\text { Ctenotus robustus, Ctenotus u. uber, Diplodactylus mitchelli, Diplodactylus pulcher, Eremiascincus richardsonii, } \\
\text { Lerista timida, Ramphotyphlops hamatus, Ramphotyphlops waitii, Strophurus wellingtonae, Tympanocryptis } \\
\text { cephalus, Tympanocryptis sp. nov., Varanus caudolineatus }\end{array}$ \\
\hline 3 & $\begin{array}{l}\text { Ctenotus ariadnae, Ctenotus iapetus, Ctenotus schomburgkii (east), Lerista labialis, Lerista petersoni, Lerista rolfei, } \\
\text { Liopholis striata, Moloch horridus, Strophurus jeanae, Strophurus strophurus }\end{array}$ \\
\hline 4 & $\begin{array}{l}\text { Carlia munda, Carlia triacantha, Ctenophorus c. caudicinctus, Ctenotus rubicundus, Ctenotus saxatilis, } \\
\text { Cyclodomorphus m. melanops, Diplodactylus galaxias, Diplodactylus savagei, Egernia aff. depressa, Gehyra } \\
\text { 'fenestra', Gehyra pilbara, Gehyra punctata, Heteronotia binoei, Lerista jacksoni, Lerista muelleri, Lerista verhmens, } \\
\text { Lucasium wombeyi, Menetia s. surda, Morethia ruficauda exquisita, Nephrurus wheeleri cinctus, Notoscincus } \\
\text { butleri, Proablepharus reginae, Ramphotyphlops grypus, Varanus acanthurus }\end{array}$ \\
\hline 5 & $\begin{array}{l}\text { Crenadactylus sp. nov., Cryptoblepharus buchananii, Ctenotus rutilans, Egernia pilbarensis, Heteronotia spelea, } \\
\text { Heteronotia sp. B, Lerista flammicauda, Lerista neander, Lerista zietzi, Oedura marmorata, Ramphotyphlops ganei, } \\
\text { Varanus pilbarensis }\end{array}$ \\
\hline 6 & $\begin{array}{l}\text { Ctenotus nasutus, Ctenotus quattuordecimlineatus, Ctenotus rufescens, Ctenotus schomburgkii (west), } \\
\text { Diporiphora pindan, Eremiascincus musivus, Lerista aff. bipes, Lerista ips, Lerista separanda, Lucasium } \\
\text { stenodactylum, Strophurus ciliaris aberrans }\end{array}$ \\
\hline
\end{tabular}

Table 5 Differences in physical attributes between the two species groups at each higher order fusion point in the dendrogram resulting from the classification of reptile taxa based on their occurrence at quadrats $(\mathrm{N}=297)$ in the Pilbara region, using Mann-Whitney U-tests. Only significant variables are shown - without brackets, $P<0.0001$ (in brackets, $P<0.005$ ). See Appendices B-D in McKenzie et al. (2009) for environmental attribute codes and explanations.

\begin{tabular}{|c|c|c|}
\hline Group level & Groups compared & Predictor environmental variables for the new groups formed \\
\hline 2 & $1-5$ v. 6 & $\begin{array}{l}\text { totP, totN, exCa, P, -TdrQ, -Tann, Silt, -soilD, Asp, orgC, -Sand, -Lat, pH, } \\
\text { Fmax, -Riv, -Sun, exK, -TweQ, -Long, -TcoQ, exMg, EC, Fabu, Clay, PcoQ, } \\
\text { totK, (-isoT), (-Psea), (-TwmQ), (exNa), (Tsea), (-mnTcP), (Elev), (Outcrp), } \\
\text { (-PweQ) }\end{array}$ \\
\hline 3 & $1-3$ v. $4-5$ & $\begin{array}{l}\text {-Rug500, -Outcrp, -Slp, -orgC, -totN, -Fmax, -Fabu, soilD, -totP, -Pann, } \\
\text {-PweQ, -exCa, -PwmQ, (-Asp), (Sun), (-PweP), (-Silt), (-exMg), (-P), (Sand) }\end{array}$ \\
\hline 4 & 1 v. $2-3$ & $\begin{array}{l}\text { Lat, isoT, Psea, PweP, -Tsea, TdrQ, Tann, -Tar, TcoQ, PwmQ, -Cst, -Elev, } \\
\text { mnTcP, PweQ, (Pann), (-mxTwP), (Outcrp) }\end{array}$ \\
\hline 5 & 2 v. 3 & (exMg), (Asp), (-Sand), (exK), (Silt), (-Riv), (exCa), (Fmax), (Clay) \\
\hline 6 & 4 v. 5 & -orgC, (exMg), (-Rug500), (-Slp), (-Tar), (exNa), (EC) \\
\hline 15 & 1a v. $1 b$ & $\begin{array}{l}\text { Fabu, Fmax, exCa, totN, (orgC), (exMg), (Rug500), (Silt), (-Sand), (totP), } \\
\text { (Clay), (exK), (-TcoQ), (Elev), (-mnTcP), (Tsea), (-soilD), (-isoT), (-Psea), } \\
\text { (-Tann), (-TdrQ), (Cst), (-Lat), (Tar) }\end{array}$ \\
\hline
\end{tabular}


Table 6 Differences in physical attributes between the two quadrat groups at each higher order fusion point in the dendrogram resulting from the classification of the 297 quadrats in the Pilbara region, using Mann-Whitney $\mathrm{U}$ tests. Fusions involving a group with five or less quadrats are omitted from the table. Only significant variables are shown - without brackets, $P<0.0001$ (in brackets, $P<0.005$ ). See Appendices B-D in McKenzie et al. (2009) for environmental attribute codes and explanations.

\begin{tabular}{|c|c|c|}
\hline Group level & Groups compared & Predictor environmental variables for the new groups formed \\
\hline 2 & A-F v.G-H & $\begin{array}{l}\text {-Rug500, -Slp, soilD, -Fmax, -Outcrp, -Fabu, -orgC, -totN, (-totP), (-Tdir), } \\
\text { (-exCa) }\end{array}$ \\
\hline 3 & A-B v. C-F & -Sand, exMg, Clay, Silt, exCa, exK, exNa \\
\hline 4 & C-E v. F & $\begin{array}{l}\text { Elev, Tsea, Cst, -TcoQ, -isoT, -mnTcP, Silt, -Lat, -Tann, Tar, exK, -Psea, } \\
\text {-TdrQ, totP, -Sand, totN, exCa, Fabu, exMg, orgC, Clay }\end{array}$ \\
\hline 5 & G v. H & -Outcrp, -Rug500, -Slp, -orgC, soilD, -Fmax, -totN \\
\hline 6 & A v. B & - \\
\hline 7 & C-D v. E & Lat, -Tar, -Cst, PweQ, PwmQ, Psea, PweP, -Tsea, Pann, orgC \\
\hline 8 & C v. D & $-\mathrm{exCa}$ \\
\hline
\end{tabular}

The remaining major assemblage (species groups 1-3) contained taxa that occurred across a variety of surface types but avoided steep hills and outcrops. Species groups 2 and 3 were marginally more similar to each other than to species group 1 (Figure 3). However, species group 3 contained poorly sampled taxa favouring sandy surfaces that are more widely distributed outside the Pilbara (e.g. Moloch horridus, Ctenotus ariadne, Liopholis striata). Of the taxa in this group, the most quadrats any taxon was captured in was only four throughout the entire region, again, making interpretation difficult. Species group 2 was better sampled and contained taxa that generally prefer heavy clays, or taxa that are known to occur further inland at relatively high elevations (e.g. Diplodactylus mitchelli, Tympanocryptis spp.), or with a preference for mulga woodlands (e.g. Ctenophorus reticulatus, Lerista timida). Also included in this group were the gecko Strophurus wellingtonae and goanna Varanus caudolineatus; these are arboreal shrub and woodland species with distributions to the south of the Pilbara and which were also trapped at low rates on some rocky quadrats with shrubs or trees.

Species group 1 was the largest recovered from our analysis and contained taxa that showed no strong substrate or surface type preferences, except an avoidance of steep hills and outcrops (Figure 3). This group was separated from species groups 2 and 3 by latitude and many environmental variables associated with temperature and precipitation that are correlated with latitude (Table 5). Within this group, however, visual inspection of Figure 3 revealed a further division. According to our data, species group la contained taxa that preferred sandy and loamy surfaces, and showed some tolerance for rugged substrates lower on slopes. This group was represented by such abundant taxa as Diplodactylus conspicillatus (recorded from 89 quadrats; Table 1), Lucasium 'woodwardi' (105 quadrats), Ctenotus helenae (116 quadrats), C. pantherinus (117 quadrats) and Menetia greyii (114 quadrats). In contrast, species group $1 \mathrm{~b}$ contained taxa that preferred sandy surfaces and avoided clay and rocky substrates, such as Ctenophorus isolepis, Lerista bipes, Morethia $r$. ruficauda and Varanus eremius. This environmental separation was evident in variables associated with ruggedness, such as rock fragment size and abundance, and many other variables (Table 5).

\section{Quadrat classification}

In the cluster analysis of quadrats, the first division in the dendrogram separated quadrat groups A-F and G-H (Figures 3 and 4; Table 6). Quadrat groups $G$ and $H$ (the 'rugged' set) were located in more rugged terrain, whereas quadrat groups A-F (the 'non-rugged' set) were in less rugged areas and had more sands, clays and loams that supported woodlands (Figure 4; Table 6).

The topographically rugged set of quadrats was divided into two groups, G and H. Group H had higher values of outcropping, ruggedness and rock fragment size than group $G$ (Table 6). They tended 

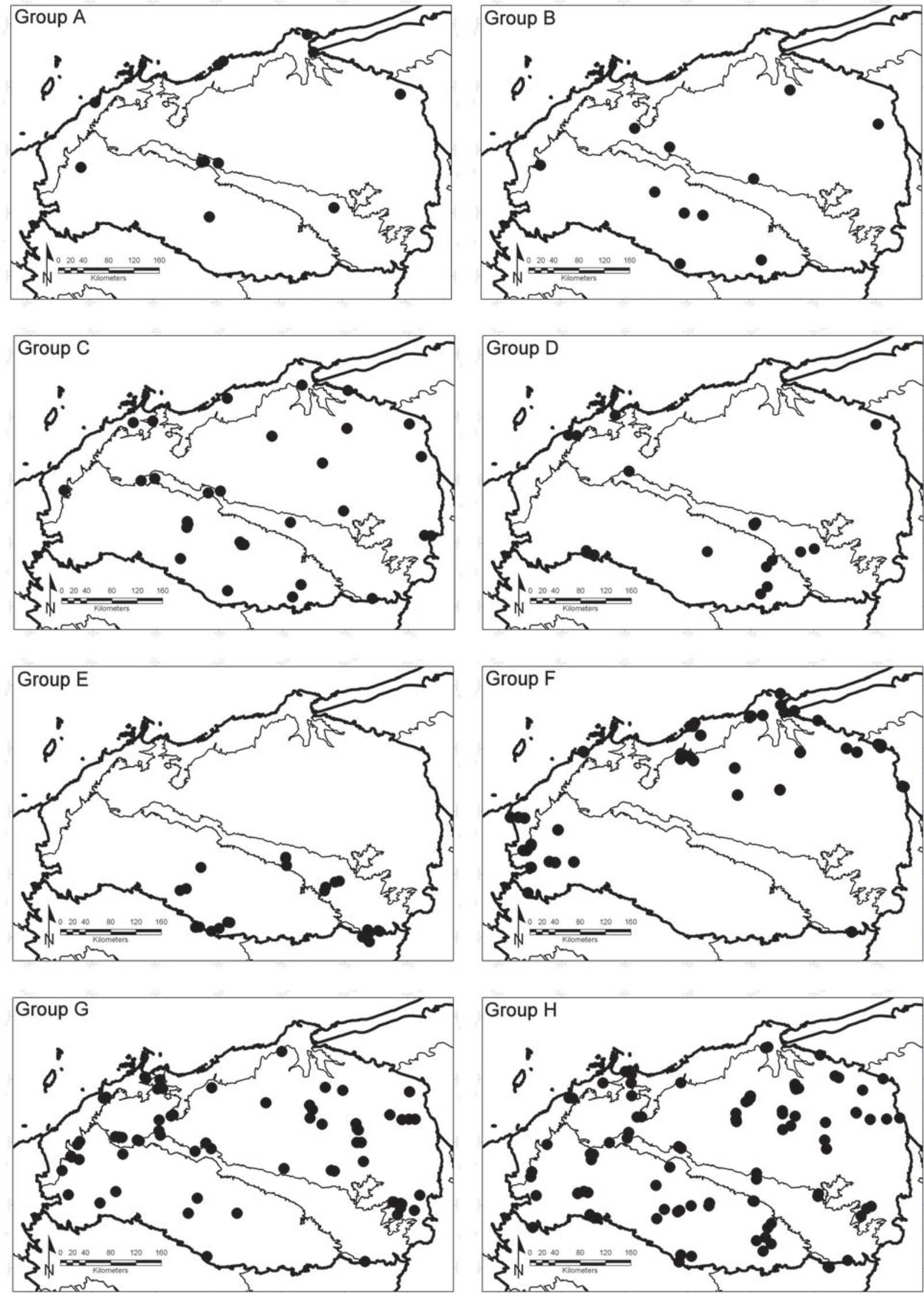

Figure 4 Distribution of the eight-group partitions in the classification of 297 quadrats in the Pilbara region, based on reptile species presence/absence. The base map shows IBRA regions and sub-regions (Thackway and Cresswell 1995; Department of Environment, Water, Heritage and the Arts 2009). 


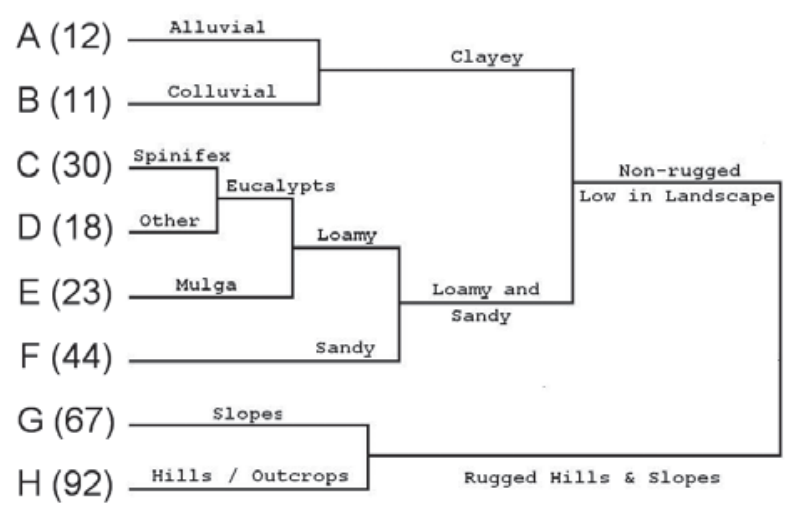

Figure 5 Eight group quadrat classification of the 297 quadrats surveyed for reptiles in the Pilbara region. Quadrats were classified on the basis of reptile species presence/absence at each quadrat. The left hand column is the quadrat group label, followed by the number of group members in brackets.

to be located higher along ridges, whereas Group G quadrats were generally positioned further down-slope. Both quadrat groups were widely distributed across the Pilbara, although they were unsurprisingly rare in the alluvial plains of the Roebourne and Fortescue subregions. An exception was group $G$ quadrats which were less common in the Hamersley sub-region than group $\mathrm{H}$ quadrats (Figure 4).

Within the non-rugged set, the first major division separated quadrats by the presence of heavy clays (groups A and B) compared to groups $\mathrm{C}-\mathrm{F}$ which had more sandy and loamy surfaces (Figure 5, Table 6). Group A and B quadrats were widely scattered across the Pilbara, with no obvious pattern with respect to subregions, except for the absence of group B in the Roebourne subregion (Figure 4). Group A quadrats were more alluvial, whereas group $\mathrm{B}$ quadrats tended to have more colluvial-derived clays. However, because of the low number of quadrats in groups A and B (12 and 11 respectively) and the observed variation, further work is required before strong conclusions can be drawn.

Within groups $\mathrm{C}-\mathrm{F}$, group $\mathrm{F}$ contained quadrats with deeper sands compared to groups $\mathrm{C}-\mathrm{E}$, which were more loamy with a combination of clayey and sandy surfaces with tall vegetation such as mulga and Eucalyptus spp. canopies (Figure 5, Table 6). Group F quadrats were concentrated in topographically subdued areas of the far western and north-eastern Pilbara (Figure 4) and corresponded closely with species groups 6 and 1 (especially 1b) (Figure 3; Appendix 2).

Within groups $\mathrm{C}-\mathrm{E}$, group $\mathrm{E}$ quadrats were

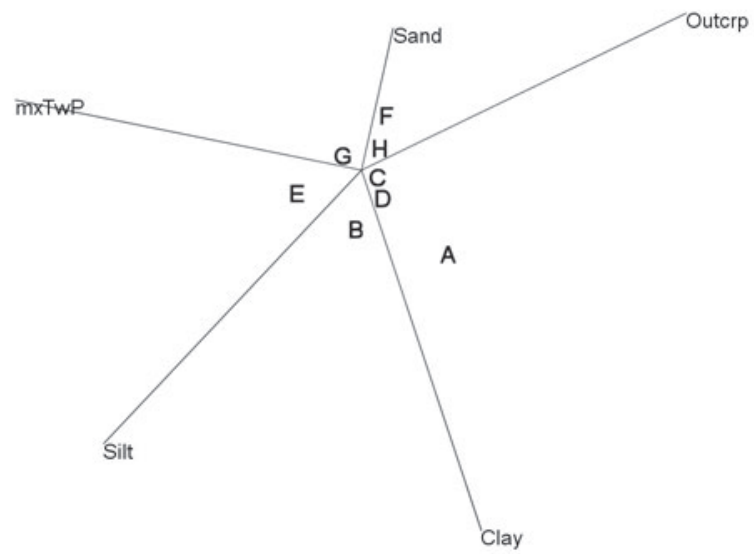

Figure 6 Ordination plot (non-metric multidimensional scaling; $\mathrm{SSH}$ ) based on the presence of reptiles at 297 quadrats in the Pilbara (plot shows group centroids only) overlain with selected environmental variables using the PCC procedure in PATN (Belbin 1995).

located in mulga woodlands, whereas groups C and D contained quadrats with a predominantly tall Eucalyptus overstorey (Figure 4, Table 6). Group E quadrats were confined to the southern Pilbara, on the inland portion of the Fortescue Marsh, the Hamersley Range and to the east of Newman (Figure 4). Accordingly, there were significant differences in latitude and weather and precipitation variables associated with their positions within the region (Table 6).

Lastly, groups C and D both had quadrats with tall Eucalyptus overstorey, but group D quadrats lacked a dense spinifex understorey whereas this was present in group C quadrats. We noticed the skink Ctenotus pantherinus had a strong aversion to quadrats in group $\mathrm{D}$, probably indicating a requirement for spinifex to provide shelter or other essential resources. Group C quadrats were widely distributed in the Pilbara region, but group D quadrats were concentrated in coastal areas, in the Fortescue Marsh and the southern Hamersley subregion, with many associated with the valleys of major Pilbara rivers, i.e, the De Grey, Fortescue and Ashburton Rivers (Figure 4).

Table 7 shows the species that provided best discrimination between groups at the whole analysis level, on the basis of the Kruskal-Wallis statistic.

The ordination of 297 quadrats resulted in a complex plot (3D stress $=0.25$ ), without obvious groupings. Therefore, in Figure 6 we plot the group centroids, using the groups identified above in the cluster analysis. Relationships between the ordinated quadrats and six environmental variables (identified from the clustering analysis, above) were assessed using principal component correlation (PCC in 
Table 7 Reptile species providing the best discrimination among quadrat groups $(\mathrm{A}-\mathrm{H})$, as judged by the magnitude of the Kruskal-Wallis statistic. Mean occurrence (proportion of quadrats within each group in which the species was recorded) is given for each species in each cluster group; figures in bold are the highest value for a given species.

\begin{tabular}{|c|c|c|c|c|c|c|c|c|c|}
\hline & $\begin{array}{c}\text { Kruskal- } \\
\text { Wallis }\end{array}$ & Group & & & & & & & \\
\hline Species & value & A & B & $\mathrm{C}$ & D & $\mathrm{E}$ & $\mathbf{F}$ & G & $\mathbf{H}$ \\
\hline Ctenotus saxatilis & 101.47 & 0.17 & 0 & 0.47 & 0.06 & 0 & 0.43 & 0.78 & 0.93 \\
\hline Ctenophorus caudicinctus & 84.34 & 0.17 & 0.73 & 0.47 & 0.11 & 0.43 & 0.20 & 0.91 & 0.88 \\
\hline Ctenophorus isolepis & 77.29 & 0 & 0.09 & 0.33 & 0.06 & 0.39 & 0.89 & 0.13 & 0.02 \\
\hline Lerista bipes & 75.38 & 0 & 0 & 0.33 & 0 & 0.04 & 0.84 & 0.04 & 0.02 \\
\hline Morethia ruficauda exquisita & 72.69 & 0 & 0 & 0.20 & 0 & 0.13 & 0.32 & 0.33 & 0.79 \\
\hline Ctenotus helenae & 67.69 & 0 & 0 & 0.57 & 0.39 & 0.65 & 0.64 & 0.64 & 0.07 \\
\hline Ctenotus pantherinus & 61.33 & 0.08 & 0.45 & 0.60 & 0.06 & 0.13 & 0.73 & 0.64 & 0.15 \\
\hline Diplodactylus conspicillatus & 54.06 & 0.17 & 0 & 0.40 & 0 & 0.39 & 0.73 & 0.43 & 0.05 \\
\hline Ctenotus duricola/piankai & 53.53 & 0.08 & 0.09 & 0 & 0 & 0.30 & 0.45 & 0.70 & 0.21 \\
\hline Lucasium 'woodwardi' & 48.03 & 0 & 0.09 & 0.53 & 0.22 & 0.78 & 0.61 & 0.42 & 0.12 \\
\hline Varanus acanthurus & 43.55 & 0.17 & 0 & 0.10 & 0 & 0.04 & 0.16 & 0.3 & 0.60 \\
\hline Gehyra punctata & 38.97 & 0 & 0 & 0.07 & 0 & 0.04 & 0.14 & 0.25 & 0.54 \\
\hline Heteronotia binoei & 37.84 & 0 & 0.18 & 0.50 & 0.28 & 0.22 & 0.36 & 0.76 & 0.35 \\
\hline Menetia greyii & 34.18 & 0 & 0.09 & 0.43 & 0.83 & 0.26 & 0.48 & 0.31 & 0.27 \\
\hline Carlia munda & 33.17 & 0 & 0 & 0.67 & 0.50 & 0.04 & 0.02 & 0.28 & 0.25 \\
\hline Gehyra variegata/purpurascens & 31.26 & 0 & 0 & 0.53 & 0.61 & 0.57 & 0.43 & 0.13 & 0.21 \\
\hline Ctenophorus reticulatus & 29.63 & 0.42 & 0.09 & 0.17 & 0 & 0.65 & 0.05 & 0.03 & 0 \\
\hline Menetia surda & 23.03 & 0 & 0 & 0.17 & 0.17 & 0.04 & 0.02 & 0.46 & 0.25 \\
\hline Lerista clara & 22.84 & 0 & 0 & 0.03 & 0 & 0 & 0.45 & 0 & 0 \\
\hline Varanus brevicauda & 20.48 & 0.08 & 0 & 0.17 & 0.11 & 0.09 & 0.27 & 0.43 & 0.05 \\
\hline Pogona m. minor & 18.57 & 0.25 & 0.27 & 0.27 & 0.06 & 0.30 & 0.48 & 0.18 & 0.05 \\
\hline Lerista muelleri & 18.15 & 0 & 0.36 & 0.17 & 0.61 & 0.17 & 0.02 & 0.09 & 0.24 \\
\hline Rhynchoedura ornata & 18.09 & 0.08 & 0.09 & 0.43 & 0 & 0.22 & 0.30 & 0.04 & 0.02 \\
\hline Ramphotyphlops ammodytes & 16.08 & 0 & 0.09 & 0.27 & 0.11 & 0.04 & 0.39 & 0.36 & 0.11 \\
\hline Lucasium wombeyi & 15.64 & 0 & 0.09 & 0 & 0 & 0.13 & 0.02 & 0.33 & 0.26 \\
\hline Cyclodomorphus melanops & 14.17 & 0 & 0 & 0.27 & 0.11 & 0 & 0.02 & 0.34 & 0.21 \\
\hline Gehyra 'fenestra' & 14.11 & 0 & 0 & 0 & 0 & 0 & 0.07 & 0 & 0.28 \\
\hline Diplodactylus savagei & 13.97 & 0 & 0 & 0 & 0 & 0.04 & 0 & 0.07 & 0.29 \\
\hline Ctenotus grandis titan & 13.83 & 0 & 0 & 0.03 & 0.06 & 0.13 & 0.36 & 0.28 & 0.09 \\
\hline Varanus eremius & 13.68 & 0.08 & 0 & 0.10 & 0 & 0.09 & 0.39 & 0.06 & 0.02 \\
\hline Amphibolurus longirostris & 13.08 & 0.17 & 0 & 0.43 & 0.28 & 0.13 & 0.07 & 0.07 & 0.04 \\
\hline Nephrurus levis pilbarensis & 12.47 & 0 & 0 & 0.07 & 0 & 0 & 0.34 & 0.01 & 0 \\
\hline Ctenotus rubicundus & 11.38 & 0 & 0 & 0 & 0 & 0.09 & 0 & 0.10 & 0.27 \\
\hline Ctenotus uber & 11.18 & 0 & 0 & 0.07 & 0.11 & 0.43 & 0 & 0.06 & 0.01 \\
\hline Ctenophorus nuchalis & 10.79 & 0.33 & 0.36 & 0.10 & 0.06 & 0.22 & 0.27 & 0.12 & 0.01 \\
\hline
\end{tabular}


PATN, Belbin 1995). $R^{2}$ values of the six plotted variables were quite low, averaging 0.02. However, Monte Carlo simulations (MCAO in PATN, Belbin 1995) revealed that for Sand, Silt, Clay and mxTwp, less than $5 \%$ of computed $R^{2}$ values exceeded the actual $R^{2}$ values for each attribute, while for Outcrop and Rug500 the figures were $21 \%$ and $46 \%$, respectively, indicating that rocky outcrops and ruggedness are less useful predictors in the global analysis. This plot conforms to the patterns described above, but the links with environmental variables are more readily discerned in the outputs from the clustering analysis, where groups of quadrats can be analysed separately.

\section{DISCUSSION}

Our survey of the Pilbara herpetofauna found clear associations between species assemblages and three major surface types: rock, clay and sandy loam. Within this structure, however, we often observed taxa occurring on more than one surface type, indicating the importance of other environmental factors and the mosaic of different habitat types in Pilbara landscapes. This juxtaposition of habitat types probably contributed to overlap of taxa across quadrat groups but should be viewed as a real pattern within the region, and not merely 'noise' in the underlying association of species and surface type (e.g. species dispersal or sampling artefacts). Other taxa had much more restricted habitat requirements and occurred only on rock, clay or sand, and some of these taxa also had small ranges within the Pilbara region. Climatic variables showed less influence on assemblage composition than did surface type but were significant for some of the groups that emerged from our analysis.

The survey benefited from an intensive sampling scheme in which nearly 300 quadrats were sampled for two weeks across a wide array of habitats throughout the region. The species accumulation analysis indicated that our sampling regime was more than sufficient to document the herpetological assemblages accurately at the scale of region, survey area or quadrat group. Despite the large sampling effort, the sampling design still had a number of shortcomings, most of which are unavoidable in a large survey in a region with high species diversity and taxonomic uncertainty in some groups. Several environmental variables known or thought to influence the patterning of reptile communities were probably measured imprecisely and future surveys could examine microhabitats in more detail. The influence of leaf litter or shrub distribution and density close to pitfall traps has an impact on capture rates of lizard species (Law and Dickman 1998; Daly et al. 2007) and, through their impact on vegetation, recent fire events or fire history may also influence assemblages at the time of sampling (Pianka 1996; Schlesinger et al. 1997; Letnic et al. 2004; Price et al. 2010).

Our sampling methods were unable to sample all the herpetofauna adequately, especially frogs, pygopods, terrestrial snakes and large goannas (Table 2). These groups have traditionally been difficult to sample in broad-scale surveys reliant on pitfall trapping (Rolfe and McKenzie 2000; Thompson et al. 2003). Future survey work could use other trapping techniques such as funnel traps (Fitch 1951; Enge 2001; Ribeiro-Junior et al. 2008) or more active searching (Rolfe and McKenzie 2000) to increase the capture of some snakes and pygopods and opportunistic searching after rainfall events to survey frogs by captures or call identification.

Nevertheless, collections of reptiles and frogs made during the survey have clarified distributions and taxonomic boundaries of many taxa. Recent systematic research in a number of groups using genetic methods, however, indicates that some taxa currently harbour cryptic diversity. Resolution of such groups could result in greater precision for future community analyses but, given the large number of taxa already included in our analysis ( $>$ $100)$, such changes are not likely to affect our main conclusions (cf. McKenzie et al. 2000a). Indeed, greater taxonomic resolution will likely lead to even stronger assemblage/surface-type associations. A noteworthy result of our survey was that many new or synonomised taxa were vouchered and have provided the material for new descriptions (e.g. Smith and Adams 2007; Mecke et al. 2009; Doughty et al. 2010, 2011; Catullo et al. 2011) or are the subject of current revisions. Resolution of these taxonomic problems will likely lead to even higher diversity estimates to the already high herpetofaunal diversity recognised in the region.

In the discussion below, we first review the environmental associations with the various species and quadrat groups identified from our analysis. Next, we examine the spatial distributions of the region's many endemic taxa in order to understand patterns of endemism and biogeographic connections with neighbouring regions. We do this in light of the species groups identified in our analysis, in an effort to understand how habitat preferences can result in (or limit) speciation among groups adapted to different kinds of substrates or surface types. We briefly review biogeographic patterns in frogs, as they provide a less diverse assemblage that reflects many of the same patterns observed in the region's reptile fauna. Last, we consider threats to species and examine whether the current reserve system is adequate to preserve the region's herpetological diversity. 


\section{Reptile assemblage patterns related to habitat features}

The classification of species and quadrats revealed clear patterns in reptile assemblages based on surface type and habitat characteristics and, to a less extent, some general climatic variables. There were strong associations of species with rocky habitats that are typical of the Pilbara (massive outcropping ironstones and other sediments) and eroded land surfaces associated with this geology. As might be expected in the Pilbara, saxicoline assemblages are widespread in the region with the exception of the immense alluvial surfaces along the Fortescue River drainage and coastal plains in the Roebourne subregion. Within these assemblages, however, many taxa appeared across several of the quadrat groups in our analysis, reflecting the influence of other factors and/or the mosaic of habitat-types within the dispersal capabilities of the taxa involved.

The species from the most topographically rugged quadrats (usually steep rock containing numerous crevices interspersed by patches of skeletal soils with spinifex grassland) included a number of Pilbara endemics. Geckos such as Diplodactylus galaxias, D. savagei, Gehyra punctata and G. 'fenestra'; the skinks Egernia cygnitos, E. epsisolus, E. pilbarensis, Ctenotus rutilans and Morethia ruficauda exquisita; and the blind snake Ramphotyphlops ganei, are all endemic to rocky ranges in the Pilbara or extend slightly beyond the region to nearby rocky outliers in the Gascoyne region such as Mount Augustus and the Kennedy, Carnarvon and Collier Ranges. A conspicuous feature of many of these taxa is a rich reddish colouration that matches the colour of the ironstones throughout the region and especially in the Hamersley subregion.

The other saxicoline species group occurred on eroded rocky surfaces that were less topographically rugged than the massive outcropping rock. Quadrats with these characteristics were distributed widely across the Pilbara, reflecting their areal contribution to the region's landscapes. The reptile assemblages at these quadrats included species with large geographic distributions, so that the Pilbara was only a small proportion of the range, or they were situated on the margin of a more extensive range. Some of these species possessed large northern arid zone distributions (e.g. Carlia triacantha and Ctenotus saxatilis; or extensive central and southern arid zone distributions (e.g. Proablepharus reginae, Cyclodomorphus m. melanops and Ramphotyphlops grypus). The grouping also included a number of Pilbara endemics. The apparently disparate nature of the species forming this group suggests that the biophysical features affecting their distribution are variable, or that they followed subtle environmental variables not measured in our survey. Further sampling would be required to tease apart the habitat determinants of these species.

The assemblages observed on 'non-rugged' quadrats (groups A-F) occurred on surfaces ranging from heavy clays, sandy loams with tall vegetation, to deep aeolian sands. We discuss clayey quadrats first, then sandy and loamy quadrats. Land surfaces with heavy clays are relatively uncommon in the Pilbara and only a few such quadrats were sampled along the coastal plain of the Roebourne subregion and in the Fortescue drainage. These typically had low diversity of reptile species. Because of the low numbers of quadrats and the apparent lower rate of species accumulation during sampling in some of these areas (Table 3), it is difficult to draw detailed conclusions, so we have restricted the discussion to broad-scale trends.

Quadrats with clayey soils (groups A and B) and either mulga woodland or tussock grassland (group E) were clustered in the south-eastern Pilbara, around Tom Price and Paraburdoo, in the upper Fortescue River drainage and on the southeastern edge of the region bordering the Gascoyne IBRA region (Figure 5). They had distinctive reptile assemblages of predominantly widespread species that occur in mulga woodlands and shrublands in adjoining regions to the south and east of the Pilbara. This includes arboreal species such as Strophurus wellingtonae, Caimanops amphiboluroides and Varanus caudolineatus. These species occur in the Pilbara so long as there is sufficient tree cover for the animals to perch, forage or shelter under bark. Lizards that prefer open habitats with compacted clayey soil and sparse plant cover included Diplodactylus pulcher, Ctenophorus reticulatus, Tympanocryptis spp., Ctenotus leonhardii, C. uber and Lerista timida) (Pianka 1986; Wilson and Knowles 1988; Ehmann 1992). The endemic gecko Diplodactylus mitchelli is a crackingclay specialist that occurs in these habitats within the Chichester Range, and has evolved with a flattened body and long limbs compared to its near relatives. Presumably, these adaptations enable it to retreat deep into crevices. This species, along with the two Tympanocryptis species, potentially represent instances of speciation of clay specialists owing to being isolated in the rocky Pilbara region from their sister taxa to the south (Doughty et al. 2008; Shoo et al. 2008).

The other major group of habitat types identified in the analysis was associated with surfaces generally termed sandy loams. The species classification identified two groups ( $1 \mathrm{~b}$ and 6 ) with strong association to sand. The first was a group of species that occurred on quadrats in deep sands near or outside the boundary of the Pilbara. In this sense, the Pilbara craton can be seen as excluding these taxa. One interesting exception is a new species of Lerista that is closely related to L. bipes but has diverged significantly to warrant species recognition 
(C. Stevenson et al., unpublished data). It is possible that this taxon has been separated from other L. bipes populations within the Pilbara by discontinuities in suitable sandy habitat, similar to the clay-associated taxa discussed above. Such a mechanism of speciation is the opposite of that presumed to have occurred for the majority of endemic saxicoline taxa, which have dispersed from neighbouring rocky regions and have been isolated by the sandy deserts that surround the Pilbara.

The other major group of taxa favouring sandy surfaces was species group 1a. In contrast to species group $1 \mathrm{~b}$, group $1 \mathrm{a}$ occurred on sandy surfaces but also showed a more generalist habitat preference, also occurring widely on clayey and rock surfaces throughout the region (Figure 3). This species group included taxa that are sandy desert specialists and whose ranges occur well outside the Pilbara region. Examples include the Military Dragon Ctenophorus isolepis, the sand-swimming skink Lerista bipes and the goanna Varanus eremius. This pattern suggests that the Pilbara is considered just another part of the arid zone to these sand-adapted species. The gecko Nephrurus levis has elsewhere been shown to favour the interdune environment, whereas its close relative $N$. laevissimus is a dune crest specialist (Pianka 1986). The former was reasonably common within the Pilbara (represented by the subspecies $N$. levis pilbaraensis, differing mainly in colour pattern), but N. laevissimus occurred only at one quadrat in the survey at the eastern edge of the survey area adjacent to the Little Sandy Desert. This suggests that habitats approximating the interdune environment outside the Pilbara exist within the Pilbara, enabling N. l. pilbarensis to occur, but that true sandridge environments do not occur, thereby excluding $N$. laevissimus. This group also contained some generalists that may prove to harbour cryptic species with stronger preferences for specific substrates (e.g. L. 'woodwardi' - Pepper et al. 2008; D. conspicillatus - Oliver et al. 2009; M. greyii - PD, JKR, pers. obs.). Resolution of these groups would likely strengthen environmental associations overall and reduce the number of species considered generalists in our analyses.

The study did not identify any reptile assemblage showing a strong affinity to regional riparian vegetation or sites, unlike birds (Burbidge et al. 2010) and microbats (McKenzie and Bullen 2010). This is perhaps not surprising, given that in the Pilbara there are few major drainage lines, they do not have extensive well-developed habitats that are distinct from surrounding areas, and any such habitats are scattered. Species such as Amphibolurus longirostris occur across much of the landscape, and their abundance in riverine areas may have as much to do with the structural opportunities offered by riverine vegetation as with the increased productivity and associated resources, although this is speculative. Pilbara rivers are of a size comparable with other areas - the Fortescue and De Grey drainages are hundreds of kilometres long. The absence of riparian specialist reptile fauna is more likely due to the effects of past arid climate cycles. Repeated arid phases associated with glaciation and global climate patterns may have led to very severe drying across the Pilbara (such as that experienced during the last glacial maximum). If such specialist species did once occur along Pilbara river systems, these repeated cycles of global or continental aridity probably removed them. Such a process may have contributed to the low observed patterns of endemism and specialisation to riparian ecosystems in other nonvolant groups of animals (Bowler 1976).

Unlike the Kimberley region, the Pilbara lacks large predatory reptiles that are closely associated with watercourses, such as Crocodylus johnstoni, Varanus mertensi and $V$. mitchelli. An exception is the Pilbara Olive Python (Liasis olivaceus barroni) which was recorded only once on a quadrat during our survey. It has a strong preference for riparian vegetation during warmer months when hunting for prey, but utilises rocky habitats at other times of the year (DJP, unpublished data). The freshwater turtle Chelodina steindachneri is distributed in creeks and rivers throughout the Pilbara region, extending south through the Gascoyne and Murchison catchments as far as Geraldton, and inland to the northern Goldfields. Within this region its distribution is poorly known, as turtles typically require targeted surveys to sample their presence or abundance adequately.

\section{Patterns of endemism within species groups}

In this section, we examined the whole distributions of species that occur in the Pilbara IBRA region. Our approach was to re-examine the six species groups identified from our analysis to look for strong geographic trends of endemism or for distributions that extended into regions outside the Pilbara (e.g. northern, arid or southern faunas). A focus on alpha-level species or subspecies distributions enables us to discern any obvious associations among regions at a fine-scale level. Nevertheless, where unpublished data indicated that unrecognised cryptic endemic taxa exist, we made use of this information (PD et al., unpublished data). A broader focus on the distribution of congenerics is another way to look for such relationships, but it is preferable to use existing phylogenetic information from molecular genetics as a guide for such tests. Although much progress has been made in herpetological systematics in recent years, sometimes including direct estimates of divergence time among taxa (e.g. Pepper et al. 2006; Oliver et al. 2010; Oliver and Bauer 2011), there 
is still too much uncertainty about phylogenetic structure to pursue this approach further at present. Future systematic work should greatly improve understanding of biogeographic connections of Pilbara taxa and provide rigorous tests of the patterns we present below. We discuss the groups from the top (species group 6) to the bottom (species group 1) of Figure 3 (see also Table 5 for a species list, and discussion above).

Species group 6 comprised sand specialists more widely distributed outside the Pilbara. Of the 11 taxa in this group, four occur in the arid zone to the east, such as Lucasium stenodactylum, and generally occurred only on the edges of the Pilbara craton. Two taxa occurred in the coastal northern Pilbara and three occurred to the north and east of the Pilbara. Only two taxa of Ctenotus were primarily distributed to the south. The main pattern with species group 6 was that they possess adaptations to sandy surfaces, hence the lack of a strong presence inside the Pilbara region. Although technically part of the Pilbara IBRA region, they are perhaps best regarded as taxa that the Pilbara environment excludes. Their morphological adaptations to deep sand are likely to make colonisation of large areas of the Pilbara craton difficult. An exception is the distinctive endemic fossorial Lerista aff. bipes centred in the Chichester region. This species, like L. bipes, has no forelimbs, only two toes, and is a sand-obligate species. As discussed above, dissection of sandy habitats within the Pilbara may have led directly to the divergence between the two taxa within $L$. bipes. Another exception is Eremiascincus musious that occurs primarily in the Great Sandy Desert but has a southern coastal extension into the Roebourne subregion as far as Karratha. Even in this case, the species does not penetrate very far into the Pilbara craton, but rather hugs the sandy northern coastal areas.

Species group 5 contained 12 poorly sampled taxa preferring rugged surface types. All but three are endemic to the Pilbara region, with another two extending into the Gascoyne and adjacent regions and the Common Wall Skink Cryptoblepharus buchananii being largely distributed in south-western Australia. Thus, although poorly sampled in our survey, this group comprises $75 \%$ Pilbara endemics and $92 \%$ endemic to the Pilbara-Gascoyne rocky region.

Species group 4 comprised many saxicoline species and was the second-largest species group identified (25 taxa). Included were 13 endemic taxa and three more Pilbara taxa that also extended into the Gascoyne region. There were four taxa with arid and four with northern distributions, and one other that occurred in both. In common with group 5, species group 4 contained a high number of endemic taxa: $52 \%$ were endemic to the Pilbara craton and
$68 \%$ endemic to the Pilbara-Gascoyne rocky region.

Species group 3 contained 10 poorly sampled taxa that favoured sandy surfaces. Six of these are more widely distributed in the arid zone to the east and just encroached into the study area. The other four had more southern distributions, with three occurring along the central west coast in the Carnarvon region. There were no endemic Pilbara taxa in this group. The patterns with this sandassociated assemblage mirrored those in species group 6; all these species have wide ranges outside the Pilbara region in sandy deserts, along the northern coast, and along the western coast south of the Pilbara.

Species group 2 contained 16 taxa, of which 10 had more southern distributions. This assemblage was strongly associated with clay surfaces, and especially with mulga woodlands. There was a single taxon each with more arid or northern distributions. The three endemic taxa were all heavy clay specialists (two Tympanocryptis species and Diplodactylus mitchelli), and their nearest relatives have southern and arid distributions.

Species group 1 was the largest assemblage identified with a total of 28 taxa, and comprised reptile taxa with broad preferences for surface type, occurring on quadrats with rock, clay and sand. Within this assemblage, however, 11 taxa were usually only found on quadrats with sand (species group 1b). Of the 28 taxa in this group, 23 have predominantly arid distributions (15 have distributions centred in the arid zone to the east of the Pilbara, six with arid and southern distributions and two with arid and northern distributions). Two taxa have northern distributions and there were only three endemic species (two of which were blindsnakes). This species group resembled the pattern for sand-adapted species; a large proportion of taxa occur outside the Pilbara (82\%) with few endemics (only 10\%).

To summarise, saxicoline assemblages (species groups 4 and 5) comprised 59\% endemic to the Pilbara craton and $73 \%$ to the larger PilbaraGascoyne region containing favourable rocky habitats. The clay-mulga assemblage (species group 2) had a moderate number of endemics $(19 \%)$, and contained many species with distributions to the south in mulga woodlands (63\%). The assemblages with sand associations (species groups 1, 3 and 6) had the fewest endemic taxa with only $8 \%$ (4 of 49 taxa). Thus, the clear biogeographic pattern is for saxicoline taxa to speciate within the Pilbara or Pilbara-Gascoyne regions. Furthermore, many of these taxa have northern affinities based on generic classification (pers. obs.). Although claymulga woodland sites are not widespread in the Pilbara, many affiliated taxa have strong southern connections, but with a moderate number of 
endemics. Finally, sand-associated taxa had very few Pilbara endemics compared to the other groups. A pattern emerges of species adapted to rocks appearing to be isolated in the Pilbara more readily than those on other surfaces (e.g. Pepper et al. 2006, 2010; Oliver et al. 2010; Doughty et al. 2011). In contrast, perhaps quite restrictive conditions must occur for sand or clay-associated taxa to speciate, as there are large areas of suitable habitat surrounding the Pilbara region (Doughty et al. 2008; Shoo et al. 2008).

\section{Biogeographic patterns in frogs of the Pilbara}

Although frogs were one of the major groups excluded from our analysis of community patterns, they show biogeographic patterns that mirror those of the lizards and blind snakes. The Pilbara region is host to only 13 species of frogs, slightly more diverse than the surrounding arid regions which are not diverse relative to the northern tropics, eastern coast and south-west (Slatyer et al. 2007; Tyler and Doughty 2009; Powney et al. 2009). Below we briefly review some broad patterns identifiable from distribution maps.

Endemics to the Pilbara region are Pseudophryne douglasi, Uperoleia glandulosa and $U$. saxatilis. Pseudophryne douglasi appears to have a relictual distribution, being widely isolated from other congeners. Moreover, this taxon is restricted to deep gorges or permanent springs in rocky country and occurs in low densities in scattered Pilbara locations and a few sites to the west and south in the Cape Range, Barlee Range and Mount Augustus. The genus Pseudophryne may have been more widely distributed throughout southern WA when the climate was cooler and wetter, but drying in the Miocene has likely caused their current isolated and fragmented distribution (e.g. White 1994). The genus Uperoleia has its highest diversity to the north in the Kimberley region. The two endemic species from the Pilbara are related to those species (Catullo et al. 2011). Uperoleia saxatilis (formerly U. russelli, the latter now restricted to the Gascoyne region) is broadly distributed throughout the Pilbara, whereas $U$. glandulosa has a more restricted distribution in the northern coastal Pilbara but penetrates inland along the Yule River drainage. In addition, the Pilbara, Gascoyne and Murchison populations of $L$. rubella are separated from Kimberley and Top End (Northern Territory) populations by the Great Sandy Desert.

The widespread arid zone species that occur in the Pilbara are Cyclorana maini, C. platycephala, Notaden nichollsi and Platyplectrum spenceri, which are medium to large-bodied burrowing frogs. Three occur throughout the Pilbara, but C. platycephala occurs only along the south-eastern edge of the region. For these species, the habitats where they occur in the Pilbara are similar to those occupied elsewhere in the arid zone, similar to the sandadapted reptiles considered above. Interestingly, several species with northern affinities (Cyclorana australis, Neobatrachus aquilonius, Uperoleia micromeles and $U$. talpa) are largely confined to the northern and coastal areas of the Pilbara. The connection between the Pilbara and Kimberley appears to be facilitated by a corridor of suitable habitat: a strip of more mesic shrubland along the coast bordering the Great Sandy Desert that connects the south-western Kimberley fauna to the northern coastal Pilbara. This corridor is reflected in the southern coastal extension of the Dampierland IBRA region, connecting with the Roebourne subdivision of the Pilbara IBRA region (see Figure 1, upper right). Litoria caerulea, L. nasuta and Cyclorana longipes also extend south along this corridor from the Kimberley but do not quite reach the Pilbara region. Neobatrachus sutor just reaches the region from the arid areas to the south, but is excluded from the Pilbara craton.

Frogs thus provide a simplified but complementary picture of the patterns observed in Pilbara reptiles - the presence of Pilbara-Gascoyne endemics contrasted with arid-adapted groups that occur widely outside the Pilbara region. The exception is the subtropical Kimberley species that have presumably moved along favourable habitat and rainfall gradients south to reach the Roebourne subregion of the Pilbara.

\section{Conservation implications}

Despite over a century of pastoralism, mining and other anthropogenic disturbances, there have been no known extinctions of any herpetofauna in the Pilbara. The region has comparatively few species that are listed as threatened, and the majority of these are marine turtles that are not considered by this survey. There is no evidence of a regional decline in any taxon, although distributional information for many species is poor. Recent concerns about the decline of lizard (Sinervo et al. 2010) and snake (Reading et al. 2010) species elsewhere in the world, however, highlight the problems in determining population trends and the accurate assessment of the conservation status of cryptic reptiles.

Our data show that compositional patterns of the Pilbara reptile and frog faunas can largely be represented in terms of broad surface-type categories, and historical patterns of endemism and biogeographical affinities with surrounding regions. These general associations provide a basis for assessing gaps in the regional conservation reserve system.

Only $10 \%$ of the Pilbara region is currently included in conservation reserves, although some additional areas of land are proposed to become 
conservation reserves. Pastoral leases cover around $60 \%$, a further $5 \%$ is Aboriginal reserve, and around $25 \%$ is Unallocated Crown Land, with comparatively small areas of urban and industrial land holdings (McKenzie et al. 2009). Consequently, there are opportunities for the acquisition of further conservation estate within the Pilbara. Existing Pilbara conservation reserves occur mostly in the rugged Hamersley and western Chichester subregions, which together cover around $80 \%$ of the region. Karijini and Millstream-Chichester National Parks and Mungaroona Nature Reserve total approximately 900,000 ha. These reserves are large but few in number and do not represent the range of diversity present within these sub-bioregions adequately. In particular, there are currently no conservation reserves in the distinctive sandplain/ granite boulder piles area of the central Chichester sub-region. The skink Ctenotus nigrilineatus is known from just 25 records in this habitat type.

The Roebourne Plain sub-bioregion has no lands reserved for conservation with the exception of a small portion of the Cane River Conservation Park at its extreme southern end (approximately 150,000 ha). The Roebourne Plain sub-bioregion has one restricted endemic reptile species, Lerista nevinae, on the coastal sands between Karratha and Roebourne. However, some species are seemingly more abundant in this coastal area (e.g. the largebodied skink Egernia pilbarensis) than at rockier sites further inland. The Roebourne Plain subbioregion contains species that are aligned with faunas in neighbouring coastal regions to the south or north (see above). However, the assemblages on the sampled coastal quadrats are distinctive, with species on harder surfaces characteristic of the inland Pilbara occurring in broad sympatry with species that favour sandy surfaces, reflecting the mosaic of substrate and surface types and often the loose association of species with surface type. Reservation of coastal areas to the north-east and west of Port Hedland, around the mouth of the Fortescue River and in the Karratha-Roebourne area would include these assemblages.

The assemblage of reptile species that favour heavier soils and mulga woodlands is also poorly represented within the existing reserve system. Karijini National Park contains some large areas of mulga woodlands, but woodlands to the west and south of this reserve are unrepresented. Although mulga woodlands are much more extensive in the Gascoyne and Murchison regions to the south of the Pilbara, those woodlands are also poorly represented within the current conservation reserve system. There are currently no conservation reserves along the vast sweep of the Fortescue catchment (Fortescue Plains sub-region) with the exception of a very small area within the Millstream-Chichester National
Park. While no reptile species is confined to this subregion, there are some taxa such as the Pilbara Olive Python (Liasis olivaceus barroni) and the dragons Amphibolurus longirostris and $A$. gilberti that attain their highest densities in riparian areas along the Fortescue drainage.

The adequacy and representativeness of the conservation reserve system for herpetofauna was assessed by comparing the known Pilbara herpetofauna (Table 1) with that known from existing conservation reserves. Sampling effort varies considerably among reserves: Karijini and Millstream-Chichester National Parks have been well sampled, and Cane River Conservation Reserve has been subject to a moderate level of sampling, but Mungaroona Nature Reserve has not been surveyed. Listings for three proposed reserves, Meentheena, Fortescue Marsh and 40 Mile, were also obtained for comparison. The existing conservation reserves contain the vast majority of herpetofaunal taxa known from the Pilbara bio-region. Among frogs, all occur in the existing reserves with the exception of five species. Cyclorana platycephala and Neobatrachus sutor occur widely in sandy regions to the south of the Pilbara, are explosive breeders (thus easy to miss during surveys outside major rain events) and occur only just within the Pilbara bio-region; similarly, Uperoleia micromeles is mainly an inhabitant of sandy deserts to the east, and only just extends into the Pilbara. Uperoleia glandulosa is a species restricted to the Pilbara coastal plain and Yule River and $U$. talpa extends from the Kimberley into the northern part of the Roebourne Plain; neither species is known to occur in an existing or proposed conservation reserve.

Most gecko species known from the Pilbara are represented in existing conservation reserves. Exceptions include Nephrurus laevissimus, Diplodactylus granariensis rex and Lucasium stenodactylum, taxa widespread in southern desert and semi-arid areas. Strophurus jeanae is known from the proposed Fortescue Marsh reserve, but S. ciliaris (widespread in arid Australia but uncommon in the Pilbara) and S. wilsoni (which occurs in the southern edge of the Pilbara) are not known from any existing or proposed conservation reserves in the Pilbara. All the known pygopod (legless gecko) species are represented in existing conservation reserves, except Delma borea from northern rocky spinifex sites, and $D$. desmosa which is widespread in arid regions of central and Western Australia, but just enters the north-eastern Pilbara.

Most of the species of agamids known from the Pilbara occur in existing conservation reserves with the exception of a few species that are either widespread in sandy desert regions to the east (e.g. Moloch horridus, Ctenophorus isolepis) or shrublands to the south (Ctenophorus scutulatus) or occur in 
the Pilbara region along the coastal strip from the Kimberley (Amphibolurus gilberti, Diporiphora pindan, Pogona minor mitchelli).

Despite the cryptic nature of many snakes, difficulties in sampling for their presence, and often apparently low densities, all the known Pilbara blind-snakes were recorded from existing conservation reserves. The introduced Ramphotyphlops braminus is known from some Pilbara towns but has not been recorded in any conservation reserve. Large boids were rarely encountered during the survey and there are relatively few museum specimens, as they tend to be collected rarely, especially in remote areas where preservation and transport are difficult. Nonetheless, four of the five boid species known from the Pilbara have been recorded in at least several conservation reserves (DJP, unpublished data). The Woma Python (Aspidites ramsayi) is primarily an inhabitant of sandy deserts, occurring in the Pilbara on its northern and eastern margins where suitable habitat exists. It is not known from any conservation reserve in the Pilbara, but does occur in reserves elsewhere in WA. All elapids known to occur in the Pilbara have been captured in existing or proposed conservation reserves with the exception of the fossorial elapid Simoselaps bertholdi which is widespread in central sandy deserts and in southern sandy heaths and woodlands.

Varanus gilleni, typically an inhabitant of deserts to the east of the Pilbara, is the only Pilbara varanid not recorded on an existing or proposed conservation reserve.

The one fresh-water turtle occurring in the Pilbara, Chelodina steindachneri, is known from Karijini and Millstream-Chichester National Parks.

It is for the scincid lizards that existing conservation reserves would appear to be most inadequate. A number of species do not occur within existing conservation reserves although the proposed reserves would include some of them in the conservation estate: Ctenotus nigrilineatus and Eremiascincus richardsonii in Meentheena, C. ariadne and Lerista timida/amicorum in the Fortescue Marsh and Ctenotus serventyi in 40 Mile. The Pilbara endemic Lerista neander occurs in the eastern Hamersley and Ophthalmia Ranges and has not been collected in an existing or proposed conservation reserve. Most of the other skink species not represented in the existing or proposed conservation reserves are taxa that have widespread distributions in eastern sandy deserts (species groups 3 and 6 in Table 4; e.g. Ctenotus nasutus, C. quattuordecimlineatus, Lerista ips and Liopholis striata) or more southern regions (Ctenotus severus and Lerista petersoni).

The skink Lerista nevinae is one species that appears to be particularly vulnerable because of both its habitat type (coastal sands often adjacent to major industrial development) and the small size of its geographic range (a few thousand ha. along approximately $10 \mathrm{~km}$ of coastline close to Cape Lambert). Some form of reservation for this species is necessary, given that a significant proportion of its habitat is proposed for industrial development. Further, given its coastal location and the relative isolation of the sandy habitats within which it lives, this species would appear to be the most vulnerable to rising sea level in the next few decades (including cyclonic coastal surge events) driven by global warming processes. The geomorphological processes that have generated the coastal (marinederived) sands to which this species is restricted may continue to develop habitat ahead of rising sea levels. However, while this remains conjecture, L. nevinae is still the Pilbara reptile species most likely to face significant habitat reduction and population size in the next 20 to 50 years. Similar processes will impact upon species and populations restricted to the many Pilbara islands, a habitat type not addressed in this study.

For effective conservation of herpetofauna, as well as other components of the biota, it is necessary to consider conservation measures across other land tenures and not confine biodiversity management to the existing conservation estate. Better management of the impacts of grazing stock and feral animals in riparian areas and reducing the scale of intense fire events are both likely to be significant in the conservation of reptile assemblages. These impacts occur on both conservation and nonconservation lands in the Pilbara, and will require collaborative strategies among different land-holder groups before they can be managed effectively. This will require close liaison and collaboration among conservation agencies and the various land managers in the region, including pastoralists, Aboriginal communities and mining companies. In many cases, the management of pastoral lands has been much longer-term and more active than that on Pilbara conservation reserves. Pastoral lands represent a very significant biodiversity resource while retained in their largely unimproved form, but this will not apply where intensive pasture improvement is proposed (i.e. an increase in wells and stock, introduction of Buffel Grass). Nevertheless, given the size of the Pilbara and the significance of rocky upland habitats to much of the endemic Pilbara herpetofauna, such developments, including mining and infrastructure projects, would have to achieve very large scales before their impacts were significant upon much of the fauna.

Introduced Cane Toads (Rhinella marina) pose a significant, though currently distant, threat for elements of the region's herpetofauna. Models using current and predicted climatic conditions indicate that Cane Toads could colonise much of the Pilbara region (Kearney et al. 2008; Kolbe et al. 2010). Cane Toads are known to cause deaths in some goannas, 
snakes and blue-tongue lizards through lethal toxic ingestion (recent review by Shine 2010). While Cane Toads are not known to have caused the extinction of any reptile species after their recent invasion of northern Australia, they may cause significant short-term population declines of some species (Smith and Phillips 2006). Given ongoing research on means to mitigate toad impacts on fauna through taste aversion training and other techniques ( $R$. Shine, pers. comm.), it is premature to consider what measures need to be taken now to combat toads, beyond vigilance in preventing the establishment of satellite populations from hitch-hiker toads carried in freight and on trucks.

\section{ACKNOWLEDGEMENTS}

The survey project was funded by the Western Australian Department of Environment and Conservation, with contributions from the Western Australian Museum, the Commonwealth Government through its National Heritage Trust (NHT2), and Straits Resources. In-kind support was provided by Rio Tinto Iron Ore, BHP Billiton Iron Ore and Kitchener Mining's Bamboo Creek operation.

We gratefully acknowledge each of the numerous Pilbara pastoralists and Aboriginal communities for permission to access their leases and/or land. In particular, Robyn and Tony Richardson of Mount Florance Station provided free access to their camping ground for the survey quadrat installation and sampling teams, and Rio Tinto Iron Ore provided access to subsidised housing for the first installation team while operating out of Karratha.

DEC's Pilbara Region staff in Karratha, Karijini and Millstream provided subsidised accommodation for the quadrat selection, installation and sampling teams, and the Department of Water provided access to Tabletop Hill, Harding Dam and quadrats along the West Pilbara water supply pipeline. Rio Tinto Iron Ore and BHP Billiton Iron Ore gave permission for survey teams to enter their exploration leases and use their rail access roads.

Norm McKenzie provided useful advice in relation to multivariate analyses and editorial assistance, as well as providing motivation for completing the final manuscript. Mark Cowan assisted with the analysis of species occurrence in conservation reserves, and Alex George and two anonymous reviewers provided helpful suggestions on the manuscript.

\section{REFERENCES}

Austin, M.P. (1991). Vegetation theory in relation to costefficient survey (pp 17-22). In: Margules, C.R. and Austin, M.P. (eds), Nature conservation: cost effective biological surveys and data analysis. CSIRO: Melbourne, Australia.

Beard, J.S. (1990). Plant life of Western Australia. Kangaroo
Press: Kenthurst, Australia.

Belbin, L. (1980). TWOSTEP: a program incorporating asymmetric comparisons that uses two steps to produce a dissimilarity matrix. CSIRO Division of Water and Land Resources Technical Memorandum 80/9: Canberra, Australia.

Belbin, L. (1991). The analysis of pattern in bio-survey data (pp 176-190). In: Margules, C.R. and Austin, M.P. (eds), Nature conservation: cost effective biological surveys and data analysis. CSIRO: Melbourne, Australia.

Belbin, L. (1995). PATN Technical Reference. CSIRO Division of Wildlife and Ecology: Canberra, Australia.

Bowler, J. (1976). Aridity in Australia: age, origins and expression in aeolian landforms and sediments. EarthScience Reviews 12: 279-310.

Burbidge, A.H., Johnstone, R.E. and Pearson, D.J. (2010). Birds in a vast arid upland: avian biogeographical patterns in the Pilbara region of Western Australia. Records of the Western Australian Museum, Supplement 78: 247-270.

Burbidge, A.H., McKenzie, N., van Leeuwen, S., Gibson, L., Doughty, P., Guthrie, N., Durrant, B. and Pearson, D. (2006). Between rock and a hard place: rich biological patterns amongst ancient red rocks. Landscope 21 (3): 12-19.

Burbidge, A.H., Rolfe, J.K., McKenzie, N.L. and Roberts, J.D. (2004). Biogeographic patterns in small grounddwelling vertebrates of the Western Australian wheatbelt. Records of the Western Australian Museum, Supplement 67: 109-137.

Catullo, R.A., Doughty, P., Roberts, J.D. and Keogh, J.S. (2011). Multi-locus phylogeny and taxonomic revision of Uperoleia toadlets (Anura: Myobatrachidae) from the western arid zone of Australia, with a description of a new species. Zootaxa 2902: 1-43.

Chao, A. (1987). Estimating the population size for capture-recapture data with unequal catchability. Biometrics 43: 783-791.

Cogger, H.G. (1975). Reptiles and amphibians of Australia. Second edition. Reed Publications: Chipping Norton, Australia.

Cogger, H.G. (2000). Reptiles and amphibians of Australia. Fifth edition. Reed/New Holland: Chipping Norton, Australia.

Colwell, R.K. (2006). EstimateS. Statistical estimation of species richness and shared species from samples. Version 8.0 user's guide. http://viceroy.eeb.uconn.edu/ estimates.

Cowan, M.A. and How, R.A. (2004). Comparisons of ground vertebrate assemblages in arid Western Australia in different seasons and decades. Records of the Western Australian Museum 22: 91-100.

Daly, B.G., Dickman, C.R. and Crowther, M.S. (2007). Selection of habitat components by two species of agamid lizards in sandridge desert, central Australia. Austral Ecology 32: 825-833.

Dormann at al. (2007). Methods to account for spatial autocorrelation in the analysis of species distributional data: a review. Ecography 30: 609-628.

Doughty, P., Oliver, P. and Adams, M. (2008). Systematics of stone geckos in the genus Diplodactylus (Reptilia: Diplodactylidae) from northwestern Australia, with 
a description of a new species from the Northwest Cape, Western Australia. Records of the Western Australian Museum 24: 247-265.

Doughty, P., Pepper, M. and Keogh, J.S. (2010). Morphological and molecular assessment of the Diplodactylus savagei species complex in the Pilbara region, Western Australia, with a description of a new species. Zootaxa 2393: 33-45.

Doughty, P., Kealley, L. and Donnellan, S.C. (2011). Revision of the Pygmy Spiny-tailed Skinks (Egernia depressa species-group) from western Austalia, with descriptions of three new species. Records of the Western Australian Museum 26: 115-137.

Durrant, B.J., Harvey, M.S., Framenau, V.W., Ott, R. and Waldock, J.M. (2010). Patterns in the composition of ground-dwelling spider communities in the Pilbara bioregion, Western Australia. Records of the Western Australian Museum, Supplement 78: 185-204.

Ehmann, H. (1992). Encyclopedia of Australian animals. Reptiles. Angus and Robertson: Sydney, Australia.

Enge, K.M. (2001). The pitfalls of pitfall traps. Journal of Herpetology 35: 467-478.

Faith, D.P., Minchin, P.R. and Belbin, L. (1987). Compositional dissimilarity as a robust measure of ecological distance. Vegetatio 69: 57-68.

Fitch, H.S. (1951). A simplified type of funnel trap for reptiles. Herpetologica 7: 77-80.

Greer, A.E. (1989). The biology and evolution of Australian lizards. Surrey Beatty and Sons: Chipping Norton, Australia.

Guthrie, N.A., Weir, T. and Will, K. (2010). Localised and regional patterns in ground-dwelling beetle assemblages in a semi-tropical arid zone environment. Records of the Western Australian Museum, Supplement 78: 169-184.

How, R.A. and Cowan, M.A. (2006). Collections in space and time: geographical patterning of native frogs, mammals and reptiles through a continental gradient. Pacific Conservation Biology 12: 111-133.

How, R.A. and Dell, J. (2004). Reptile assemblage of the Abydos Plain, north-eastern Pilbara, Western Australia. Journal of the Royal Society of Western Australia 87: 85-95.

How, R.A., Dell, J. and Cooper, N. (1991). Vertebrate fauna of the Abydos-Woodstock Reserve, northeast Pilbara. Records of the Western Australian Museum, Supplement 37: 78-125.

How, R.A., Dell, J. and Muir, B.G. (1988). Vertebrate fauna. Records of the Western Australian Museum, Supplement 30: 44-83.

James, C.D. (1994). Spatial and temporal variation in structure of a diverse lizard assemblage in arid Australia (pp 287-317). In: Vitt, L.J. and Pianka, E.R. (eds), Lizard ecology: historical and experimental perspectives. Princeton University Press: Princeton, U.S.A.

James, C.D. and Shine, R. (2000). Why are there so many coexisting species of lizards in Australian deserts? Oecologia 125: 127-141.

Kearney, M., Phillips, B.L., Tracy, C.R., Christian, K., Betts, G. and Porter, W.P. (2008). Modelling species distributions without using species distributions: the cane toad in Australia under current and future climates. Ecography 31: 423-434.

Kolbe, J.J., Kearney, M. and Shine, R. (2010). Modeling the consequences of thermal trait variation for the cane toad invasion of Australia. Ecological Applications 20: 2273-2285.

Law, B. and Dickman, C. (1998). The use of habitat mosaics by terrestrial vertebrate fauna: implications for conservation and management. Biodiversity and Conservation 7: 323-333.

Lee, S.-M. and Chao, A. (1994). Estimating population size via sample coverage for closed capture-recapture models. Biometrics 50: 88-97.

Leighton, K.A. (2004). Climate (pp 19-38). In: Van Vreeswyk, A.M.E., Payne, A.L., Leighton, K.A. and Hennig, P. (eds), An inventory and condition survey of the Pilbara region, Western Australia. Technical Bulletin No. 92. Western Australian Department of Agriculture: Perth, Australia.

Letnic, M., Dickman, C.R., Tischler, M.K., Tamayo, B. and Beh, C.L. (2004). The responses of small mammals and reptiles to post-fire succession and rainfall in arid Australia. Journal of Arid Environments 59: 85-114.

McKenzie, N.L. and Bullen, R.D. (2009). The echolocation calls, habitat relationships, foraging niches and communities of Pilbara microbats. Records of the Western Australian Museum, Supplement 78: 123-155.

McKenzie, N.L., Keighery, G.J., Gibson, N. and Rolfe, J.K. (2000a). Patterns in the biodiversity of terrestrial environments in the southern Carnarvon Basin, Western Australia. Records of the Western Australian Museum, Supplement 61: 511-546.

McKenzie, N.L., Rolfe, J.K., Aplin, K.P., Cowan, M.A. and Smith, L.A. (2000b). Herpetofauna of the southern Carnarvon Basin, Western Australia. Records of the Western Australian Museum, Supplement 61: 335-360.

McKenzie, N.L., van Leeuwen, S. and Pinder, A.M. (2009). Introduction to the Pilbara Biodiversity Survey, 2002-2007. Records of the Western Australian Museum, Supplement 78: 3-89.

McMahon, J.P., Hutchinson, M.F., Nix, H.A. and Ord, K.D. (1995). ANUCLIM users guide, version 1. Centre for Resource and Environmental Studies, Australian National University: Canberra, Australia.

Mecke, S., Doughty, P. and Donnellan, S. (2009). A new species of Eremiascincus (Reptilia: Squamata: Scincidae) from the Great Sandy Desert and Pilbara Coast, Western Australia and reassignment of eight species from Glaphyromorphus to Eremiascincus. Zootaxa 2246: 1-20.

Oliver, P.M., Adams, M. and Doughty, P. (2011). Molecular evidence for ten species and Oligo-Miocene vicariance within a nominal Australian gecko species (Crenadactylus ocellatus, Diplodactylidae). BMC Evolutionary Biology 10: 386 (11 pages).

Oliver, P.M., Adams, M., Lee, M.Y.S., Hutchinson, M.N. and Doughty, P. (2009). Cryptic diversity in vertebrates: molecular data double estimates of species diversity in a radiation of Australian lizards (Diplodactylus, Gekkota). Proceedings of the Royal Society B 276: 2001-2007.

Oliver, P.M. and Bauer, A.M. (2011). Systematics 
and evolution of the Australian knob-tail geckos (Neprurus, Carphodactylidae, Gekkota): plesiomorphic grades and biome shifts through the Miocene. Molecular Phylogenetics and Evolution 59: 664-674.

Pepper, M., Doughty, P., Arculus, R. and Keogh, J.S. (2008). Landforms predict phylogeographic structure on one of the world's most ancient surfaces. BMC Evolutionary Biology 8: 152 (7 pages).

Pepper, M., Doughty, P. and Keogh, J. S. (2006). Molecular phylogeny and phylogeography of the Australian Diplodactylus stenodactylus (Gekkota; Reptilia) speciesgroup based on mitochondrial and nuclear genes reveals an ancient split between Pilbara and nonPilbara D. stenodactylus. Molecular Phylogenetics and Evolution 41: 539-555.

Pepper, M., Fujita, M.K., Moritz, C. and Keogh, J.S. (2010). Palaeoclimate change drove diversification among isolated mountain refugia in the Australian arid zone. Molecular Ecology 20: 1529-1545.

Pianka, E.R. (1986). Ecology and natural history of desert lizards: analyses of the ecological niche and community structure. Princeton University Press: Princeton, U.S.A.

Pianka, E.R. (1996). Long-term changes in lizard assemblages in the Great Victoria Desert: dynamic habitat mosaics in response to wildfires (pp 191-215). In: Cody, M.L. and Smallwood, J.A. (eds), Long-term studies of vertebrate communities. Academic Press: London, U.K.

Powney, G.D., Grenyer, R., Orme, C.D.L., Owens, I.P.F. and Meiri, S. (2010). Hot, dry and different: Australian lizard richness is unlike that of mammals, amphibians and birds. Global Ecology and Biogeography 19: 386-396.

Price, B., Kutt, A.S. and McAlpine, C.A. (2010). The importance of fine-scale savanna heterogeneity for reptiles and small mammals. Biological Conservation 143: 2504-2513.

Rabosky, D.L., Reid, J., Cowan, M.A. and Foulkes, J. (2007). Overdispersion of body size in Australian desert lizard communities at local scales only: no evidence for the Narcissus effect. Oecologia 154: 561-570.

Reading, C.J., Luiselli, L.M., Akani, G.C., Bonnet, X., Amori, G., Ballouard, J.M., Filippi, E., Naulleau, G., Pearson, D. and Rugiero, L. (2010). Are snake populations in widespread decline? Biology Letters 6: 777-780.

Ribeiro-Junior, M.A., Gardner, T.A. and Avila-Pires, T.C.S. (2008). Evaluating the effectiveness of herpetofaunal sampling techniques across a gradient of habitat change in a tropical forest landscape. Journal of Herpetology 42: 733-749.

Rolfe, J.K. and McKenzie, N.L. (2000). Comparison of methods used to capture herpetofauna: an example from the Carnarvon Basin. Records of the Western Australian Museum, Supplement 61: 361-370.

Schall, J.J. and Pianka, E.R. (1978). Geographical trends in numbers and species. Science 201: 679-686.

Schlesinger, C.A., Noble, J.C. and Weir, T. (1997). Fire studies in mallee (Eucalyptus spp.) communities of western New South Wales: reptile and beetle populations in sites of differing fire history. Rangeland Journal 19: 109-205.

Shine, R. (2010). The ecological impact of invasive cane toads (Rhinella marina) in Australia. Quarterly Review of Biology 85: 253-291.
Shoo, L.P., Rose, R., Doughty, P., Austin, J.J. and Melville, J. (2008). Diversification patterns of pebble-mimic dragons are consistent with historical disruption of important habitat corridors in arid Australia. Molecular Phylogenetics and Evolution 48: 528-542.

Sinervo, B. et al. (2010). Erosion of lizard diversity by climate change and altered thermal niches. Science 328: 894-899.

Slatyer, C., Rosauer, D. and Lemckert, F. (2007). An assessment of endemism and species richness patterns in the Australian Anura. Journal of Biogeography 34: 583-596.

Smith, J.G. and Phillips, B.L. (2006) Toxic tucker: the potential impact of cane toads on Australian reptiles. Pacific Conservation Biology 12: 40-49.

Smith, L.A. and Adams, M. (2007). Revision of the Lerista muelleri species-group (Lacertilia: Scincidae) in Western Australia, with a redescription of L. muelleri (Fischer, 1881) and the description of nine new species. Records of the Western Australian Museum 23: 309-357.

Sneath, P.H.A. and Sokal, R.R. (1973). Numerical taxonomy: the principles and practice of numerical classification. Freeman: San Francisco, U.S.A.

Storr, G.M., Smith, L.A. and Johnstone, R.E. (1999). Lizards of Western Australia. I Skinks. Western Australian Museum: Perth, Australia.

Storr, G.M., Smith, L.A. and Johnstone, R.E. (2002). Snakes of Western Australia. Western Australian Museum: Perth, Australia.

Thackway, R. and Cresswell, I.D. (1995). An interim biogeographic regionalisation of Australia. Australian Nature Conservation Agency: Canberra, Australia.

Thompson, G.G. and Thompson, S.A. (2009). Comparative temperature in funnel and pit traps. Australian Journal of Zoology 57: 311-316.

Thompson, G.G., Thompson, S.A., Withers, P.C. and Pianka, E.R. (2003). Diversity and abundance of pittrapped reptiles in Australian arid and mesic habitats: biodiversity for environmental assessments. Pacific Conservation Biology 9: 120-125.

Trendall, A.F. (1990). Pilbara Craton. Geology and mineral resources of Western Australia, Memoir 3, Western Australian Geological Survey: Perth, Australia.

Tyler, M.J. and Doughty, P. (2009). Field guide to frogs of Western Australia. Western Australian Museum: Welshpool, Australia.

van Vreeswyk, A.M.E., Payne, A.L., Leighton, K.A. and Hennig, P. (eds) (2004). An inventory and condition survey of the Pilbara region, Western Australia. Technical Bulletin No. 92. Western Australian Department of Agriculture: Perth, Australia.

White, M.E. (1994). After the greening, the browning of Australia. Kangaroo Press: Kenthurst, Australia.

Wilson, S.K. and Knowles, D.G. (1988). Australia's reptiles: a photographic reference to the terrestrial reptiles of Australia. Collins: Sydney, Australia. 


\section{APPENDIX 1 [ELECTRONIC]}

Significant statistics (from Mann-Whitney U tests) relating the occurrence of each taxon to environmental variables within each of the species-groups derived from the classification analysis of reptile species at 297 quadrats in the Pilbara biogeographic region (see text for details). Species codes were derived by taking the first three letters of the generic name and the first five letters of the specific name (see Table 1 for a complete species listing). Key: $\mathrm{nAbs}=$ the number of quadrats where a given species was not detected; $\mathrm{nPrs}$ $=$ the number of quadrats where that species was detected; $\#=$ cases where $n \operatorname{Prs}<5$, invalidating use of a Mann-Whitney $\mathrm{U}$ test; green shading = negative correlation, $P<0.05$; blue shading $=$ positive correlation, $P<0.05$. Environmental variables are as described in McKenzie et al. (2009). Species groups (see Figure 3) are delineated by horizontal lines.

\section{APPENDIX 2 [ELECTRONIC]}

Data matrix re-ordered according to the results of the species and quadrat classification analyses of 101 reptile species sampled at 297 quadrats in the Pilbara biogeographic region (see text). Species codes were derived by taking the first three letters of the generic name and the first five letters of the specific name (see Table 1 for a complete species listing).

See CD inside the back cover or visit

http://www.museum.wa.gov.au/research/records-supplements/ 